\title{
Tropical cyanobacterial blooms: a review of prevalence, problem taxa, toxins and influencing environmental factors
}

\author{
Maxine A.D. MOWE, ${ }^{1 *}$ Simon M. MITROVIC, ${ }^{2}$ Richard P. LIM, ${ }^{2}$ Ambrose FUREY, ${ }^{3}$ Darren C.J. YEO ${ }^{1}$ \\ ${ }^{1}$ Freshwater \& Invasion Biology Laboratory, Department of Biological Sciences, National University of Singapore, 14 Science Drive \\ 4, Singapore 117543; ${ }^{2}$ Centre for Environmental Sustainability, School of the Environment, University of Technology, Sydney, PO \\ Box 123, Broadway NSW 2007, Australia; ${ }^{3}$ Mass Spectrometry Research Centre (MSRC), Department of Physical Sciences, Cork \\ Institute of Technology, Bishopstown, Cork, Ireland \\ *Corresponding author: maxinemowe@gmail.com
}

\begin{abstract}
Toxic cyanobacterial blooms are a major issue in freshwater systems in many countries. The potentially toxic species and their ecological causes are likely to be different in tropical zones from those in temperate water bodies; however, studies on tropical toxic cyanobacterial blooms are sporadic and currently there is no global synthesis. In this review, we examined published information on tropical cyanobacterial bloom occurrence and toxin production to investigate patterns in their growth and distribution. Microcystis was the most frequently occurring bloom genus throughout tropical Asia, Africa and Central America, while Cylindrospermopsis and Anabaena blooms occurred in various locations in tropical Australia, America and Africa. Microcystis blooms were more prevalent during the wet season while Cylindrospermopsis blooms were more prevalent during the dry period. Microcystin was the most encountered toxin throughout the tropics. A meta-analysis of tropical cyanobacterial blooms showed that Microcystis blooms were more associated with higher total nitrogen concentrations, while Cylindrospermopsis blooms were more associated with higher maximum temperatures. Meta-analysis also showed a positive linear relationship between levels of microcystin and N:P (nitrate:phosphate) ratio. Tropical African Microcystis blooms were found to have the lowest microcystin levels in relation to biomass and N:P (nitrate:phosphate) compared to tropical Asian, Australian and American blooms. There was also no significant correlation between microcystin concentration and cell concentration for tropical African blooms as opposed to tropical Asian and American blooms. Our review illustrates that some cyanobacteria and toxins are more prevalent in tropical areas. While some tropical countries have considerable information regarding toxic blooms, others have few or no reported studies.
\end{abstract}

Key words: Cyanobacterial blooms, tropical areas, toxin production, Microcystis, Cylindrospermopsis, N:P.

Received: April 2014. Accepted: November 2014.

\section{INTRODUCTION}

Cyanobacterial blooms have been recognised as a health issue in freshwater systems in many countries (Briand et al., 2003; Falconer, 2008) mainly because some species are capable of producing potent toxins that are harmful to humans and animals. Currently there are two types of cyanotoxins that are particularly problematic to humans: hepatotoxins (cyclic peptides) and neurotoxins (alkaloids) (Sivonen, 1999; Stewart et al., 2008; Wiegand and Pflugmacher, 2005; Zurawell et al., 2005; Chen et al., 2009). Toxin-producing cyanobacteria have been responsible for serious cases of human and livestock poisoning and deaths in a number of countries worldwide (e.g., in Brazil, Australia and North America) (Francis, 1878; Beasley et al., 1989; Azevedo et al., 2002; Cox et al., 2005; Sotero-Santos et al., 2006).

In one of the most serious incidents in the tropics, 116 kidney dialysis patients in Northeast Brazil suffered from liver failure, resulting in 52 fatalities, due to dialysis water that was sourced from a nearby reservoir contaminated with microcystins in 1996 (Carmichael, 1996; Joachimsen et al., 1998; Carmichael et al., 2001; Komarek et al., 2001; Azevedo et al., 2002). Since that incident some studies have been carried out on several reservoirs in South and Central America documenting blooms and progenitor species (Díaz-Pardo et al., 1998; Carmichael et al., 2001; Lind and Davalos-Lind, 2002; Ramirez et al., 2002; Bittencourt-Oliveira et al., 2005; Frias et al., 2006; Merino-Ibarra et al., 2007; Berry and Lind, 2010; Vasconcelos et al., 2010; Rejmánková et al., 2011). A review by Dorr et al. (2010) revealed that there has been increased cyanobacterial bloom occurrence in water bodies in South America requiring better methods for screening and testing of cyanobacterial toxins.

Another case of human hepatoenteritis caused by cyanobacterial toxin poisoning in a tropical area occurred on Palm Island, Australia, in 1979, where 148 adults and children were affected by the toxin in their drinking water taken from a lake with high levels of the cyanobacterial species Cylindrospermopsis raciborskii, which is known to produce cylindrospermopsin, a newly identified hepa- 
totoxin at that time (Hawkins et al., 1985). These cases illustrate the importance and need to understand the toxin producing cyanobacterial species, their prevalence and causes of blooms.

Although cyanobacterial blooms are a worldwide phenomenon, there are differences in the typical species and toxins found in temperate and tropical areas (Bartram et al., 1999). However, most published studies focus on cyanobacterial toxins and blooms in temperate regions with considerably less work reported from tropical areas. Nevertheless, as demonstrated by the cyanotoxin cases in Brazil and Australia, toxic cyanobacterial blooms in tropical countries can occur with considerable harmful effect. Within the tropics, cyanobacterial toxins and blooms have been more intensively studied in certain countries such as Brazil, Australia and Thailand, but an overall global review of blooms in the tropics is lacking. This review aims to address this gap by highlighting cyanobacterial bloom studies undertaken in tropical areas. In this review, data on the i) prevalence, problem taxa, toxin production and ii) influencing environmental factors for toxic cyanobacterial blooms is assessed for tropical countries across four continents. This information is synthesised and evaluated to reveal trends across tropical countries, which may be different from those in sub-tropical and temperate locations.

\section{METHODS}

The literature was located using Web of Science and Google Scholar using the keywords: cyanobacteria, blooms, tropics and tropical countries, with specific country searches for the period between 1970 and 2013. For the purpose of this review, the word bloom was defined as Alert Level 1 by the World Health Organization (Bartram et al., 1999), which denotes high biomass (cell counts of 2000 cells $\mathrm{mL}^{-1}$ or $0.2 \mathrm{~mm}^{3} \mathrm{~L}^{-1}$ biovolume or $1 \mu \mathrm{g} \mathrm{L}^{-1}$ chlorophyll $a$ ) of cyanobacterial species in a water body. In total, 142 papers covering 186 water bodies were obtained from regional and international journals for the qualitative discussion of overall trends in cyanobacterial blooms. Percentages of dominant cyanobacterial bloom genera were calculated for all the tropical blooms reported. A subset of 66 papers covering 91 water bodies was chosen based on information on cyanobacteria toxins found, for example, microcystins (MC-RR \& MC-LR) were found via LC-MS testing. These papers were used to calculate percentage of different cyanobacterial toxins detected for the toxic tropical cyanobacterial blooms reported.

A subset of 33 papers covering 48 water bodies was selected for a meta-analysis of environmental factors influencing bloom formation. The criterion for choosing these 33 studies was availability of data on the identification of the bloom species, highest total nitrogen concentration ( $\mathrm{TN}, \mathrm{mg} \mathrm{L}^{-1}$ ), highest total phosphorus concentration (TP, $\mathrm{mg} \mathrm{L}^{-1}$ ), and minimum and maximum temperatures. In order to ascertain which factors were more important for tropical bloom formation, metadata on environmental variables and genera of cyanobacteria were examined for relationships using non-metric multidimensional scaling (NMDS) (R, Vegan package, Oksanen et al., 2013). Blooms were arranged by presence or absence of dominant genera (Microcystis, Cylindrospermopsis, Anabaena, and Planktothrix). An NMDS was run on the genera data, which contained 48 data points from tropical Asia, America, Australia and Africa. As cyanobacterial biomass was not recorded by all of the 33 studies it was not used as a criterion for the metaanalysis. The environmental variables (highest total nitrogen concentration, highest total phosphorus concentration, total nitrogen to total phosphorus ratio based on molar ratios, minimum and maximum temperatures) were then fitted onto the NMDS using envfit (R, Vegan package, Oksanen et al., 2013). To analyse the effect of types of water bodies on cyanobacterial bloom genera present, the meta-data created above was analysed using NMDS and Adonis (Permutational Multivariate Analysis of Variance using Distance Matrices) and plotted using ordiellipse (R, Vegan package, Oksanen et al., 2013).

In order to analyse the relationship between nutrient levels and microcystin levels, eight papers covering 14 water bodies were selected based on the availability of information for i) maximum total microcystin concentration $\left(\mu \mathrm{g} \mathrm{L} \mathrm{L}^{-1}\right)$; ii) nitrate $\left(\mathrm{mg} \mathrm{L}^{-1}\right)$ in the water body at the time of the maximum microcystin concentration; iii) phosphate (orthophosphate/soluble reactive phosphorous, $\left.\mathrm{PO}_{4}\right)\left(\mathrm{mg} \mathrm{L}^{-1}\right)$ in the water body at the time of the maximum microcystin concentration. A regression analysis on nitrate, phosphate, N:P (nitrate: phosphate), and maximum total microcystin concentration was then carried out using Spearman's correlation coefficient (rho). For the analysis of maximum temperatures and microcystin concentration, 11 papers covering 17 water bodies were selected based on the availability of information on i) maximum (highest) temperatures of water body during sampling and ii) maximum total microcystin concentration $\left(\mu \mathrm{g} \mathrm{L}^{-1}\right)$. A regression analysis on the maximum temperature of the water body and the maximum total microcystin concentration was carried out using Spearman's correlation coefficient (rho). For the analysis of Microcystis biomass and microcystin concentration, eight papers covering 27 water bodies were selected based on availability of information: i) total microcystin concentration ( $\left.\mu \mathrm{g} \mathrm{L}^{-1}\right)$; ii) cell count of Microcystis from the same water body. A regression analysis on the Microcystis cell count and microcystin concentration was then carried out using Spearman's correlation coefficient (rho). 


\section{RESULTS AND DISCUSSION}

\section{Prevalence, problem taxa, toxin production}

\section{General patterns of cyanobacteria and cyanotoxins across tropical areas}

Microcystis was the most prevalent bloom-causing genus in tropical Africa and Asia, while Cylindrospermopsis was the most common in tropical Australia and the second most prevalent genus in tropical Asia (Fig. 1). Microcystis and Cylindrospermopsis blooms have occurred in similar frequency in tropical America. Anabaena blooms were the second most frequently occurring genus in tropical Africa. As expected, the frequency of cyanobacterial bloom occurrence in tropical Australia was much lower compared to that of other tropical countries, due to the relatively smaller land area of tropical northern Australia.

The most frequently encountered toxin throughout the tropics was microcystin except for tropical Australia where cylindrospermopsin was more frequently encountered (Fig. 2). The frequent occurrence of cylindrospermopsin in Australia was expected given the higher frequency of recorded Cylindrospermopsis blooms (Griffiths and Saker, 2003). The second most encountered toxin in Africa was anatoxin, produced by blooms of $\mathrm{An}$ abaenopsis, Arthrospira and Anabaena species (Ballot et al., 2005; Odokuma and Isirima, 2007). Despite the presence of Anabaena in tropical Asia, anatoxin was not detected, with the only two toxins detected being microcystin and cylindrospermopsin. The lack of expertise required for testing for neurotoxins may partly account for the lack of documented occurrences (Jewel et al., 2003).

Saxitoxin was detected in tropical American and tropical African blooms by HPLC and various other detection

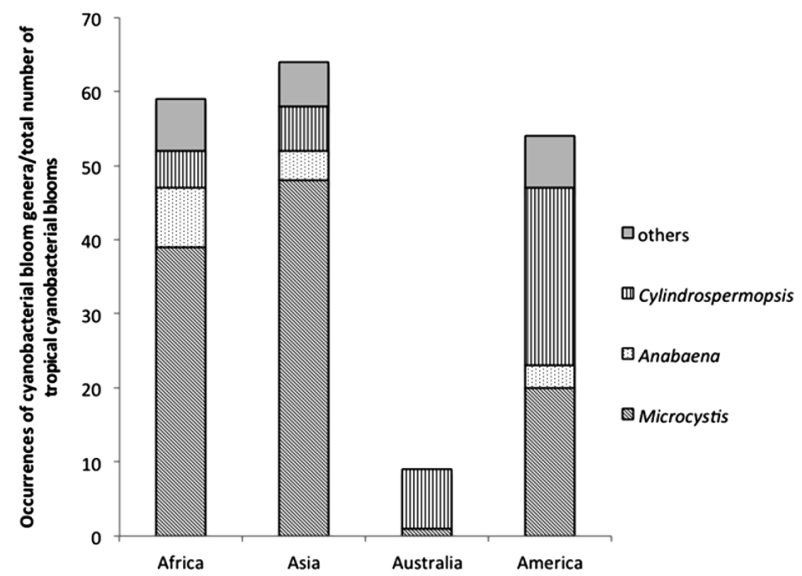

Fig. 1. Proportion of tropical cyanobacterial genera, out of total number of tropical cyanobacterial blooms. methods (ESI, LC-MS, FLD). This toxin was produced by blooms of Cylindrospermopsis and Lyngbya in Brazil, Mexico, Guatemala and Nigeria (Lagos et al., 1999; Bouvy et al., 1999; Molica et al., 2005; dos Anjos et al., 2006; Berry and Lind, 2010; Rejmánková et al., 2011; Sant'Anna et al., 2011). Comparisons of the neurotoxic Cylindrospermopsis strains from Brazil and Mexico revealed the Brazilian strain to have acute neurotoxicity from the presence of saxitoxin, neosaxitoxin and decarbamoylsaxitoxin and the Mexican strains isolated were found to be non-toxic (Bernard et al., 2003).

\section{Patterns in toxin testing across the tropics}

The percentage of cyanobacterial blooms that undergo toxin testing has increased in tropical Africa and America and remained relatively constant in tropical Australia from the 1990s to the present, but decreased in tropical Asia. Many blooms that occur in tropical Asia are not tested for toxins despite reports of fish kills or harm to livestock (Tab. 1); this could be due to a lack of expertise and cyanotoxin testing equipment (Jewel et al., 2003). Another reason could be a greater focus on the general limnology of lake ecosystems rather than cyanobacterial bloom formation or its management (Mizuno and Mori, 1970; Lewis 1973, 1978; Green et al., 1976, 1978). Toxin testing in India, Bangladesh, Philippines, Singapore, Sri Lanka, Thailand, and Vietnam have been carried out using HPLC (high performance liquid chromatography) and various detection methods from UV (ultraviolet) to MALDI-TOF (matrix assisted laser desorption time of flight mass spectrometry) (Tab. 1). Blooms in Australian water bodies were tested using mouse bioassays in the 1990s, and later by HPLC for more detailed toxin results (Saker and Griffiths, 2001; Griffiths and Saker, 2003; White et al., 2003; Bor-

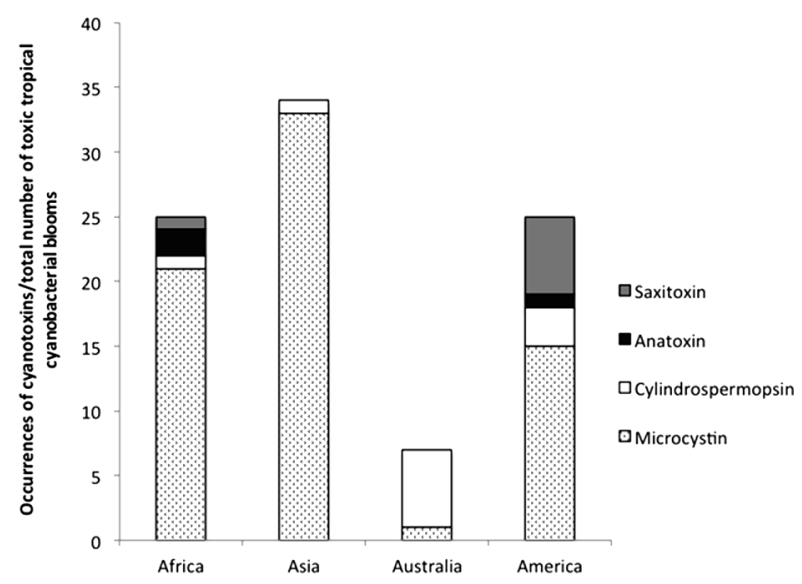

Fig. 2. Proportion of different cyanobacterial toxins, out of total number of toxic tropical cyanobacterial blooms. 
mans et al., 2004). In the case of tropical Africa, many of the blooms were detected in reservoirs and lakes used for drinking water, highlighting a need for toxicity testing in these countries (Akin-Oriola et al., 2006). Past studies of bloom occurrence and toxin testing via ELISA test kits/HPLC and MALDI-TOF MS have been carried out in
Ethiopia, Ghana, Nigeria, Uganda, Kenya, Tanzania and Zimbabwe but few or no studies in other central African countries, such as The Democratic Republic of Congo, Central African Republic and South Sudan (Tab. 2, Fig. 3).

An increase in toxin testing in tropical America was most prominently seen in Brazil, Mexico and Guatemala

Tab. 1. Summary of cyanobacterial blooms, prevalence and toxins recorded in tropical Asia and Australia.

$\begin{array}{lllll}\text { Country } & \text { Potential toxic species found } & \text { Toxin test } & \text { Toxins found } & \text { Amount of toxins } \\ \text { Australia } & \text { Cylindrospermopsis raciborskii*, } & \text { Mouse bioassay } & \text { CYN \& MC } & \text { CYN: } 1.0-20 \mu \mathrm{g} / \mathrm{L}, \mathrm{MC}: \\ & \begin{array}{l}\text { Aphanizomenon } \text { sp., Anabaena } \mathrm{sp} ., \\ \text { Anabaena } \text { tenericaulis \& }\end{array} & \text { \& HPLC/MS } & & 1000-2500 \mu \mathrm{g} / \mathrm{L} \\ & \text { Microcystis panniformis* } & & \end{array}$

References

Hawkins et al., 1985;

Hawkins and Griffiths, 1993;

McGregor and Fabbro, 2000;

Saker and Griffiths, 2001;

Griffiths and Saker, 2003;

White et al., 2003;

Bormans et al., 2004

\begin{tabular}{|c|c|c|c|c|c|}
\hline Bangladesh & $\begin{array}{l}\text { Microcystis aeruginosa*, } \\
\text { Microcystis sp.*, } \\
\text { Anabaena flos-aquae \& } \\
\text { Planktothrix sp. }\end{array}$ & $\begin{array}{l}\text { RP-HPLC \& } \\
\text { HPLC/LCMS \& } \\
\text { HPLC/UV }\end{array}$ & MC-LR,-RR,-YR & $0.14-1360 \mu \mathrm{g} / \mathrm{L}$ & $\begin{array}{l}\text { Welker } \text { et al., 2004; } \\
\text { Ahmed et al., 2008; } \\
\text { Ahmed and Luckas, 2008; } \\
\text { Jahan et al., } 2010\end{array}$ \\
\hline Cambodia & Microcystis aeruginosa & Not tested & Not tested & Not tested & Campbell et al., 2006 \\
\hline Hong Kong & $\begin{array}{l}\text { Microcystis aeruginosa, } \\
\text { M. Incerta \& } \\
\text { Anabaena flos-aquae }\end{array}$ & Not tested & Not tested & Not tested & Hodgkiss, 1974 \\
\hline India & $\begin{array}{l}\text { Microcystis aeruginosa*, } \\
\text { M. novacekii, M. viridis*, } \\
\text { M. wesenbergii \& M. icthyoblabe }\end{array}$ & $\begin{array}{l}\text { RP-HPLC/ } \\
\text { MALDI-TOF \& } \\
\text { RP-HPLC/ } \\
\text { LC/ESI/MS }\end{array}$ & MC-LR,-RR & $280-1540 \mu \mathrm{g} / \mathrm{g}$ & $\begin{array}{l}\text { Agrawal } \text { et al., 2006; } \\
\text { Tyagi et al., 2006; } \\
\text { Prakash } \text { et al., 2009; } \\
\text { Sangolkar } \text { et al., } 2009\end{array}$ \\
\hline Indonesia & $\begin{array}{l}\text { Microcystis aeruginosa, } \\
\text { Cylindrospermopsis raciborskii \& } \\
\text { Planktothrix agardhii }\end{array}$ & Not tested & Not tested & Not tested & $\begin{array}{l}\text { Padisak, 1997; } \\
\text { Prihantini } \text { et al., 2008; } \\
\text { Retnaningdyah et al., } 2010\end{array}$ \\
\hline Malaysia & $\begin{array}{l}\text { Microcystis spp., } \\
\text { Cylindrospermopsis raciborskii \& } \\
\text { Planktothrix agardhii }\end{array}$ & Not tested & Not tested & Not tested & $\begin{array}{l}\text { Rouf et al., 2008; } \\
\text { Harith and Hassan, 2011; } \\
\text { Mansoor et al., } 2011\end{array}$ \\
\hline Myanmar & Microcystis spp. & Not tested & Not tested & Not tested & Green, 2010 \\
\hline Philippines & $\begin{array}{l}\text { Microcystis aeruginosa*, } \\
\text { Cylindrospermopsis raciborskii }\end{array}$ & $\begin{array}{l}\text { HPLC/ } \\
\text { MALDI-TOF }\end{array}$ & MC-LR & $11472-12158 \mu \mathrm{g} / \mathrm{g}$ & $\begin{array}{l}\text { Cuvin-Aralar et al., 2002; } \\
\text { Baldia et al., 2003; } \\
\text { Baldia et al., } 2007\end{array}$ \\
\hline Singapore & $\begin{array}{l}\text { Microcystis spp.*, } \\
\text { Cylindrospermopsis raciborskii, } \\
\text { Planktothrix sp. Anabaena sp. \& } \\
\text { Aphanizomenon sp. }\end{array}$ & HPLC/LC-MS & MC-LR & $2660-2800 \mu \mathrm{g} / \mathrm{L}$ & $\begin{array}{l}\text { Yang and Chiam-Tai, 1991; } \\
\text { Sim, 2009; Te and Gin, } 2011\end{array}$ \\
\hline Sri Lanka & $\begin{array}{l}\text { Microcystis aeruginosa*, } \\
\text { M.incerta*, Anabaena } \text { sp. \& } \\
\text { Planktothrix sp. }\end{array}$ & HPLC/ET-MS & MC-LR,-RR & $0.8-81 \mu \mathrm{g} / \mathrm{L}$ & Jayatissa et al., 2006 \\
\hline Thailand & $\begin{array}{l}\text { Microcystis aeruginosa*, } \\
\text { M. wesenbergii \& } \\
\text { Cylindrospermopsis raciborskii* }\end{array}$ & ELISA/HPLC-MS & $\begin{array}{l}\text { MC-LR,-RR,-YR, } \\
\text { CYN }\end{array}$ & $\begin{array}{l}\text { MC: } 2.2 \pm 3.0 \mu \mathrm{g} / \mathrm{L} \text { and } \\
9.4 \pm 2.0 \mu \mathrm{g} / \mathrm{L} \\
\text { CYN: } 1020 \mu \mathrm{g} / \mathrm{g}\end{array}$ & $\begin{array}{l}\text { Mahakhant et al., 1998; } \\
\text { Li et al., 2001; } \\
\text { Wang et al., 2002; } \\
\text { Prommana et al., 2006; } \\
\text { Khuantrairong et al., } 2008\end{array}$ \\
\hline Vietnam & $\begin{array}{l}\text { Microcystis spp.*, Jaaginema sp., } \\
\text { Arthrospira masartii, } \\
\text { Oscillatoria perornata, } \\
\text { Planktothrix zahidii \& } \\
\text { Pseudanabaena cf. moniliformis* }\end{array}$ & ELISA/HPLC-UV & MC-LR,-RR & $\begin{array}{l}2.94 \mu \mathrm{g} / \mathrm{L} \text { and } \\
18.94 \mu \mathrm{g} / \mathrm{L}\end{array}$ & $\begin{array}{l}\text { Nguyen } \text { et al., 2007a; } \\
\text { Nguyen } \text { et al., 2007b; } \\
\text { Dao et al., } 2010\end{array}$ \\
\hline
\end{tabular}

MC, Microcystin; CYN, Cylindrospermopsin; * species tested for toxins. 
with testing carried out via mouse and fish bioassay, ELISA \& HPLC/PDA, MALDI-TOF (Tab. 3). This increase was probably motivated by the two incidents that led to human fatalities in 1988 and 1996 (Teixeira et al., 1993; Domingos et al., 1999; Carmichael et al., 2001; Azevedo et al., 2002; Molica 2002). Few studies have been conducted in other countries such as Panama and Colombia (Bartram et al., 1999; Dorr et al., 2010).

\section{Problem taxa - Prevalence in tropical water bodies and toxins produced}

\section{Microcystis}

\section{Tropical Asia and Australia}

The majority of blooms (77\%) in tropical Asia were caused by Microcystis spp., usually Microcystis aeruginosa (Fig. 1; Tab. 1). Several species (M. aeruginosa, M. no-

Tab. 2. Summary of cyanobacterial blooms, prevalence and toxins recorded in tropical Africa.

\begin{tabular}{|c|c|c|c|c|c|}
\hline Country & Potential toxic species found & Toxin test & Toxins found & Amount of toxins & References \\
\hline Cameroon & $\begin{array}{l}\text { Planktothrix mougeotii, } \\
\text { Oscillatoria putrida \& } \\
\text { Microcystis spp. } \\
\text { (M.aeruginosa, M. wesenbergii) }\end{array}$ & Not tested & Not tested & Not tested & $\begin{array}{l}\text { Kemka et al., 2003; } \\
\text { Green, } 2010\end{array}$ \\
\hline Cote d'lvoire & Unknown bloom-forming species & Not tested & Not tested & Not tested & $\begin{array}{l}\text { Bouvy et al., 1998; } \\
\text { Arfi et al., } 2001\end{array}$ \\
\hline Ethiopia & Microcystis sp.* & ELISA & No MC found & No MC found & Gremberghe et al., 2011 \\
\hline Ghana & $\begin{array}{l}\text { Microcystis aeruginosa* } \& \\
\text { Anabaena flos-aquae }\end{array}$ & HPLC & MC-RR & $0.03-3.21 \mu \mathrm{g} / \mathrm{L}$ & Addico et al., 2006 \\
\hline Kenya & $\begin{array}{l}\text { Microcystis aeruginosa*, } \\
\text { Arthrospira fusiformis* \& } \\
\text { Anabaenopsis abijatae* }\end{array}$ & $\begin{array}{l}\text { ELISA/HPLC- } \\
\text { MALDI-TOF }\end{array}$ & $\begin{array}{l}\text { MS MC-LR \& } \\
\text { Anatoxin-a }\end{array}$ & $\begin{array}{l}\mathrm{MC}: 1.6-39.0 \mu \mathrm{g} / \mathrm{g} \\
\text { Anatoxin: } 0.5-2.0 \mu \mathrm{g} / \mathrm{g}\end{array}$ & $\begin{array}{l}\text { Ballot et al., 2005; } \\
\text { Haande et al., 2007; } \\
\text { Kotut et al., } 2010\end{array}$ \\
\hline Nigeria & $\begin{array}{l}\text { Cylindrospemopsis sp*. } \\
\text { Anabaena } \text { sp.*, Microcystis sp.* } \\
\text { (Microcystis aeruginosa, } \\
\text { M. flos-aquae, M. wesenbergii), } \\
\text { Lyngbya sp.*, } \\
\text { Aphanizomenon flos-aquae, } \\
\text { Oscillatoria limnetica \& } \\
\text { Anabaena spiroides }\end{array}$ & $\begin{array}{l}\text { ELISA/ } \\
\text { HPLC-MALDI- } \\
\text { TOF }\end{array}$ & $\begin{array}{l}\text { MC, CYN, } \\
\text { Anatoxin-a, } \\
\text { Anatoxin-a(s), } \\
\text { STX }\end{array}$ & MC: $1.4-3.8 \mu \mathrm{g} / \mathrm{L}$ & $\begin{array}{l}\text { Anadu et al., 1990; } \\
\text { Kemdirim, 2000; Ezra and } \\
\text { Nwankwo, 2001; } \\
\text { Akin-Oriola, 2003; } \\
\text { Akin-Oriola et al., 2006; } \\
\text { Odokuma and Isirima, 2007; } \\
\text { Chia et al., 2009; } \\
\text { Okechukwu and Ugwumba, } \\
\text { 2009; Onyema, 2010; } \\
\text { Ajuzie, } 2012\end{array}$ \\
\hline Senegal & $\begin{array}{l}\text { Microcystis aeruginosa \& } \\
\text { Cylindrospermopsis raciborskii }\end{array}$ & Mouse bioassay & $\begin{array}{l}\text { No CYN/STX } \\
\text { found }\end{array}$ & No CYN/STX found & $\begin{array}{l}\text { Berger et al., 2006; } \\
\text { Bouvy et al., 2006; } \\
\text { Dufour et al., } 2006\end{array}$ \\
\hline Tanzania & Anabaena sp., Microcystis sp.* & $\begin{array}{l}\text { HPLC-DAD/ } \\
\text { MALDI-TOF }\end{array}$ & MC-RR & $0-1.0 \mu \mathrm{g} / \mathrm{L}$ & Sekadende et al., 2005 \\
\hline Zimbabwe & $\begin{array}{l}\text { Microcystis aeruginosa*, } \\
\text { M. wesenbergii, M. novacekii, } \\
\text { C. raciborskii, Lyngbya } \text { sp., } \\
\text { Anabaena } \mathrm{sp} ., \text { Aphanizomenon sp. } \\
\text { \& Oscillatoria } \mathrm{sp} .\end{array}$ & ELISA & MC-LR & $0.2-22.48 \mu \mathrm{g} / \mathrm{L}$ & $\begin{array}{l}\text { Ramberg, 1987; } \\
\text { Magadza, 2006; } \\
\text { Mhlanga et al., 2006a; } \\
\text { Mhlanga et al., 2006b; } \\
\text { Magadza, 2008-2009; } \\
\text { Kunz, 2011; Tendaupenyu, } \\
\text { 2012; Mhlanga, n.d. }\end{array}$ \\
\hline
\end{tabular}

MC, Microcystin; CYN, Cylindrospermopsin; *species tested for toxins. 
vacekii, $M$. viridis, $M$. wesenbergii and $M$. ichthyoblabe) occurred as blooms in different countries and samples containing $M$. aeruginosa, $M$. viridis and $M$. incerta (now Aphanocapsa incerta) produced microcystins (microcystin LR, RR and YR) (Tab. 1). In Asia, 66\% of Microcystis blooms produced microcystins; the remaining blooms in Myanmar and Indonesia were not tested for toxins (Fig. 4, Tab. 1). Evidence from Myanmar and Indonesia were based on papers that lacked taxonomic detail and toxin analysis (Tab.1). Therefore, the cyanobacterial bloom occurrences from these countries are likely to be an underestimate of actual cyanobacterial bloom occurrences.

Microcystis blooms in Bangladesh, Sri Lanka, Vietnam, Thailand, Singapore and the Philippines have recorded microcystin levels above the WHO drinking water guideline level of $1 \mu \mathrm{g} \mathrm{L}-1$ (Cuvin-Aralar et al., 2002; Wang et al., 2002; Baldia et al., 2003; Welker et al., 2004; Jayatissa et al., 2006; Prommana et al., 2006; Nguyen et al., 2007b). In India, livestock poisoning as well as skin lesions in children were reported from the shores of lakes and reservoirs (Agrawal et al., 2006). A bloom in Bangladesh may have resulted in massive fish kills and reduction in livelihood of the communities that depend on fishing for subsistence (Jewel et al., 2003); however, no toxin analysis was carried out on the bloom and fish samples (Jewel et al., 2003). Other studies on Microcystis blooms in Bangladesh by the World Health Organization (Welker et al., 2004) confirm the presence of microcystins in the drinking water bodies.

There was only one notable Microcystis bloom in trop-

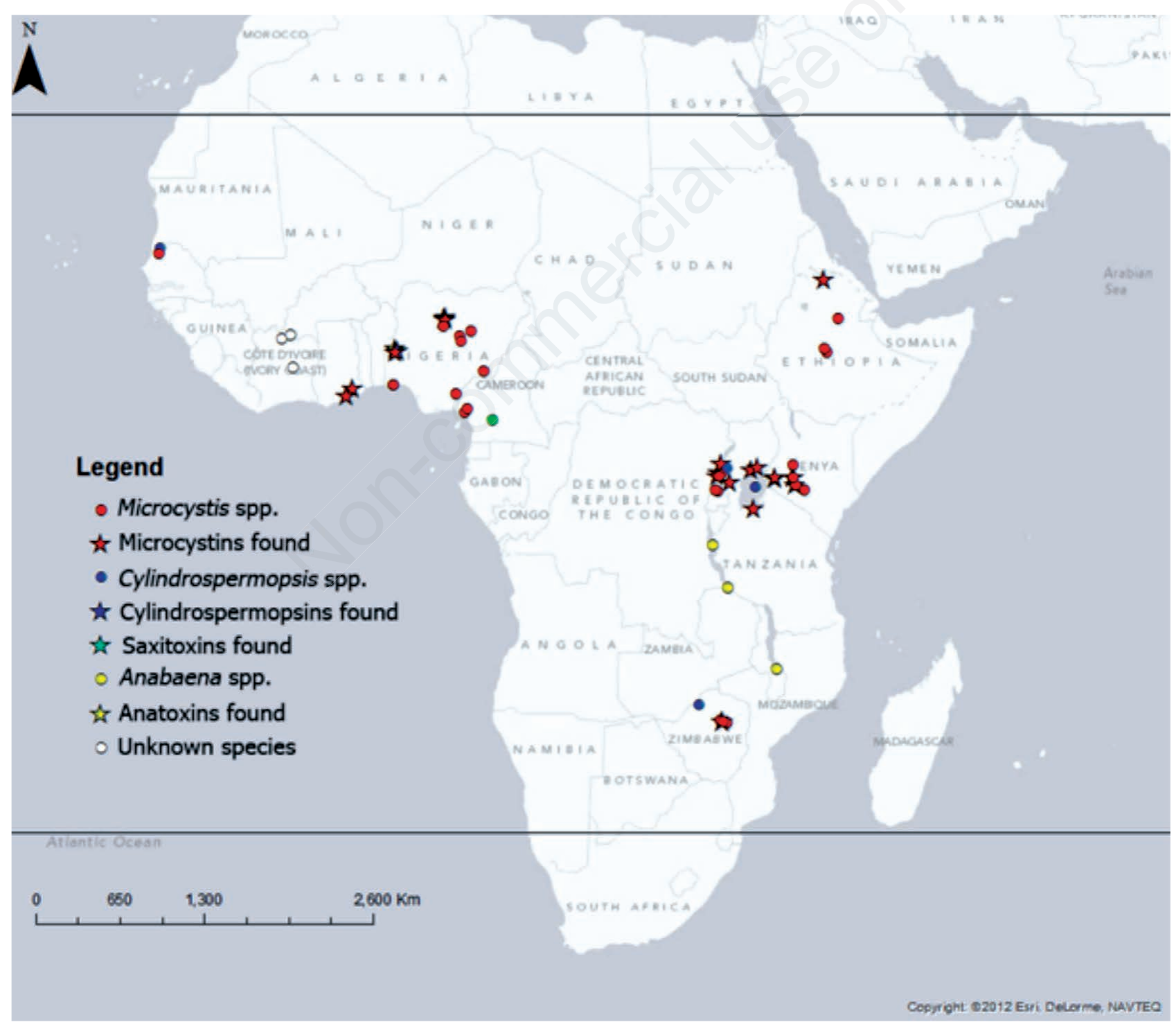

Fig. 3. Map of tropical Africa showing locations of cyanobacterial blooms, horizontal lines enclose the tropical region around the equator. 
ical Australia, recorded from Lake Elphinstone, caused by Microcystis panniformis, with a very high microcystin level of $2500 \mu \mathrm{g} \mathrm{L}^{-1}$ (White et al., 2003). It is notable that $M$. panniformis was not found to produce high levels of toxins in tropical Asia (Tab. 1) although it formed a bloom with extremely high toxin levels in tropical Australia.

\section{Tropical Africa}

Microcystis was the bloom-causing genus in $66 \%$ of blooms in tropical African countries (Figs. 1 and 3; Tab. 2). The main species responsible were $M$. aeruginosa, M. flosaquae and $M$. wesenbergii, which produced microcystins (MC-RR, (Asp3) MC-RR, MC-YR, (Asp3) MC-YR, MC-LR, MC-RY, (Asp3) MC-RY) in Ethiopia, Ghana, Tanzania, Nigeria, Uganda and Zimbabwe (Tab. 2). Of these countries, microcystin levels higher than $1 \mu \mathrm{g} \mathrm{L}^{-1}$ were recorded from water bodies in Ghana, Nigeria, Uganda and Zimbabwe (Ndebele and Mhlanga, 2006; Chia et al., 2009; Kotut et al., 2010; Sitoki et al., 2012). The highest microcystin level of $61.2 \mu \mathrm{g} \mathrm{L}^{-1}$ was detected in a cyanobacterial bloom in Lake Saka, Uganda (Okello et al., 2010; Okello and Kurmayer, 2011, Poste et al., 2013). Little is known about toxin production by Microcystis blooms in Cameroon and Senegal as they have not been tested (Tab. 2).

\section{Tropical America}

In tropical America, 35\% of total blooms were caused by species of Microcystis, namely M. aeruginosa, $M$. panniformis, M. protocystis, M. novacekii and M. viridis (Figs. 1 and 5; Tab. 3), with concentrations of microcystins above

Tab. 3. Summary of cyanobacterial blooms, prevalence and toxins recorded in tropical America.

\begin{tabular}{|c|c|c|c|c|c|}
\hline Country & Potential toxic species found & Toxin test & Toxins found & Amount of toxins & References \\
\hline Brazil & $\begin{array}{l}\text { Cylindrospermopsis raciborskii*, } \\
\text { Microcystis aeruginosa*, } \\
\text { M. novacekii*, M. panniformis*, } \\
\text { M. protocystis*, M. viridis*, } \\
\text { Planktothrix agardhii*, } \\
\text { Aphanizomenon sp., Oscillatoria sp., } \\
\text { Anabaena oumiana, A. crassa; } \\
\text { Dolichospermum circinalis } \\
\text { (formerly Anabaena circinalis) \& } \\
\text { Radiocystis fernandoi* }\end{array}$ & $\begin{array}{l}\text { Mouse and fish } \\
\text { bioassay, ELISA } \\
\text { \& HPLC/PDA, } \\
\text { MALDI-TOF } \\
\text { MC-RR, } \\
\text { MC-hRhR, }\end{array}$ & $\begin{array}{l}\text { MC-LR,MC-YR, } \\
\text { CYN, STX, NEO, } \\
\text { GTX1,GTX2, } \\
\text { GTX3, GTX4, } \\
\text { Anatoxin-a(s) }\end{array}$ & $\begin{array}{l}\text { MC-LR: } 19.5 \mu \mathrm{g} / \mathrm{L} \\
\text { STX: } 9.3 \mathrm{MU} / \mathrm{mg} \\
\text { dry cells }\end{array}$ & $\begin{array}{l}\text { Branco and Senna, 1994; } \\
\text { Bouvy et al., 1999; } \\
\text { Domingos et al., 1999; } \\
\text { Bouvy et al., 2000; } \\
\text { Huszar et al., 2000; } \\
\text { Carmichael et al., 2001; } \\
\text { Azevedo et al., 2002; } \\
\text { Molica, 2002; } \\
\text { Bittencourt-Oliveira, 2003; } \\
\text { Vieira et al., 2003; } \\
\text { Vieira et al., 2005; } \\
\text { dos Anjos et al., 2006; } \\
\text { Frias et al., 2006; } \\
\text { Sotero-Santos et al., 2006; } \\
\text { Sant'Anna et al., 2007; } \\
\text { Sant'Anna et al., 2008; } \\
\text { Figueredo and Giani, 2009; } \\
\text { Werner and Laughinghouse IV, } \\
\text { 2009; Molica et al., 2005; } \\
\text { Bouvy et al., 2003; } \\
\text { Bittencourt-Oliveira et al., 2011; } \\
\text { Moura et al., 2007; } \\
\text { Ferrão-Filho et al., 2007; } \\
\text { Piccin-Santos \& Bittencourt, } \\
\text { 2012; Soares et al., 2012 }\end{array}$ \\
\hline Guatemala & $\begin{array}{l}\text { Lyngbya hieronymusii*, } \\
\text { L. birgei*, \& L. robusta* }\end{array}$ & LC-MS/MS & CYN \& STX & $\begin{array}{l}\text { CYN: } 0.6-1.2 \mathrm{ng} / \mathrm{L}, \\
\text { STX: } 2.9-5.8 \mathrm{ng} / \mathrm{L}\end{array}$ & Rejmánková et al., 2011 \\
\hline Mexico & $\begin{array}{l}\text { Microcystis aeruginosa*, } \\
\text { M. panniformis*, M. protocystis*, } \\
\text { Planktothrix agardhii*, } \\
\text { Cylindrospermopsis catemaco*, } \\
\text { C. philippinensis*, Pseudanabaena } \\
\text { mucicola, Anabaena } \text { sp., } \\
\text { Nostoc sp. \& Oscillatoria } \mathrm{sp} .\end{array}$ & $\begin{array}{l}\text { ELISA/HPLC/ } \\
\text { LC-MS/MALDI- } \\
\text { TOF }\end{array}$ & $\begin{array}{l}\text { MC-LR,-FR, } \\
\text { HYR, YR, HtYR, } \\
\text { CYN \& STX }\end{array}$ & $\begin{array}{l}\text { MC: } 4.9 \mu \mathrm{g} / \mathrm{L}-78 \mu \mathrm{g} / \mathrm{L} \\
\text { CYN: } 21.34 \pm 2.00 \mathrm{ng} / \mathrm{L} \\
\text { STX: } 5.30 \pm 2.56 \mathrm{ng} / \mathrm{L}\end{array}$ & $\begin{array}{l}\text { Díaz-Pardo et al., 1998; } \\
\text { Lind and Davalos-Lind, 2002; } \\
\text { Ramirez et al., 2002; } \\
\text { Romero, } 2002 \\
\text { Merino-Ibarra et al., 2007; } \\
\text { Berry and Lind, 2010; } \\
\text { Vasconcelos et al., 2010 }\end{array}$ \\
\hline Venezuela & $\begin{array}{l}\text { Microcystis aeruginosa, } \\
\text { Anabaena volzii, A. spiroides \& } \\
\text { Anabaenopsis sp. }\end{array}$ & Not tested & Not tested & Not tested & Lewis, 1986 \\
\hline
\end{tabular}

MC, Microcystin; CYN, Cylindrospermopsin; *species tested for toxins. 
$1 \mu \mathrm{g} \mathrm{L}{ }^{-1}$ recorded from lake and reservoir water in Mexico and Brazil (Tab. 3). Microcystins were also detected from Radiocystis fernandoi in Brazil (Vieira et al., 2003), a species that did not produce toxins in tropical Asia, Australia or Africa. The greatest number of microcystin variants (MC-LR, FR, HYR, YR, HtYR) was detected from water bodies in Mexico (Tab. 3). Although Microcystis aeruginosa was detected in Venezuela, it was not tested for toxins and thus, little is known about occurrences of microcystins in this country (Tab. 3). A study in Sao Paulo, Brazil, found that Microcystis strains could produce paralytic shellfish poisons or PSPs, namely GTX4 (47.6\%), GTX2 (29.5\%), GTX1 (21.9\%), GTX3 (1.0\%) as well as a microcystin (MC-RR) (Sant-Anna et al., 2011). The production of neu- rotoxins by Microcystis has never been recorded in any of the other tropical blooms.

\section{Cylindrospermopsis}

\section{Tropical Asia and Australia}

The second most prevalent genus in tropical Asia was Cylindrospermopsis (Figs. 1 and 4). This genus was encountered in six out of thirteen countries in tropical Asia (Tab. 1). The genus was bloom-forming in Singapore and potentially so in Thailand and Vietnam (Khoo et al., 1977; Li et al., 2001; Pongswat et al., 2004; Meesukko et al., 2007; Khuantrairong and Traichaiyaporn, 2008; Dao et al., 2010). The only bloom-forming species was Cylin-
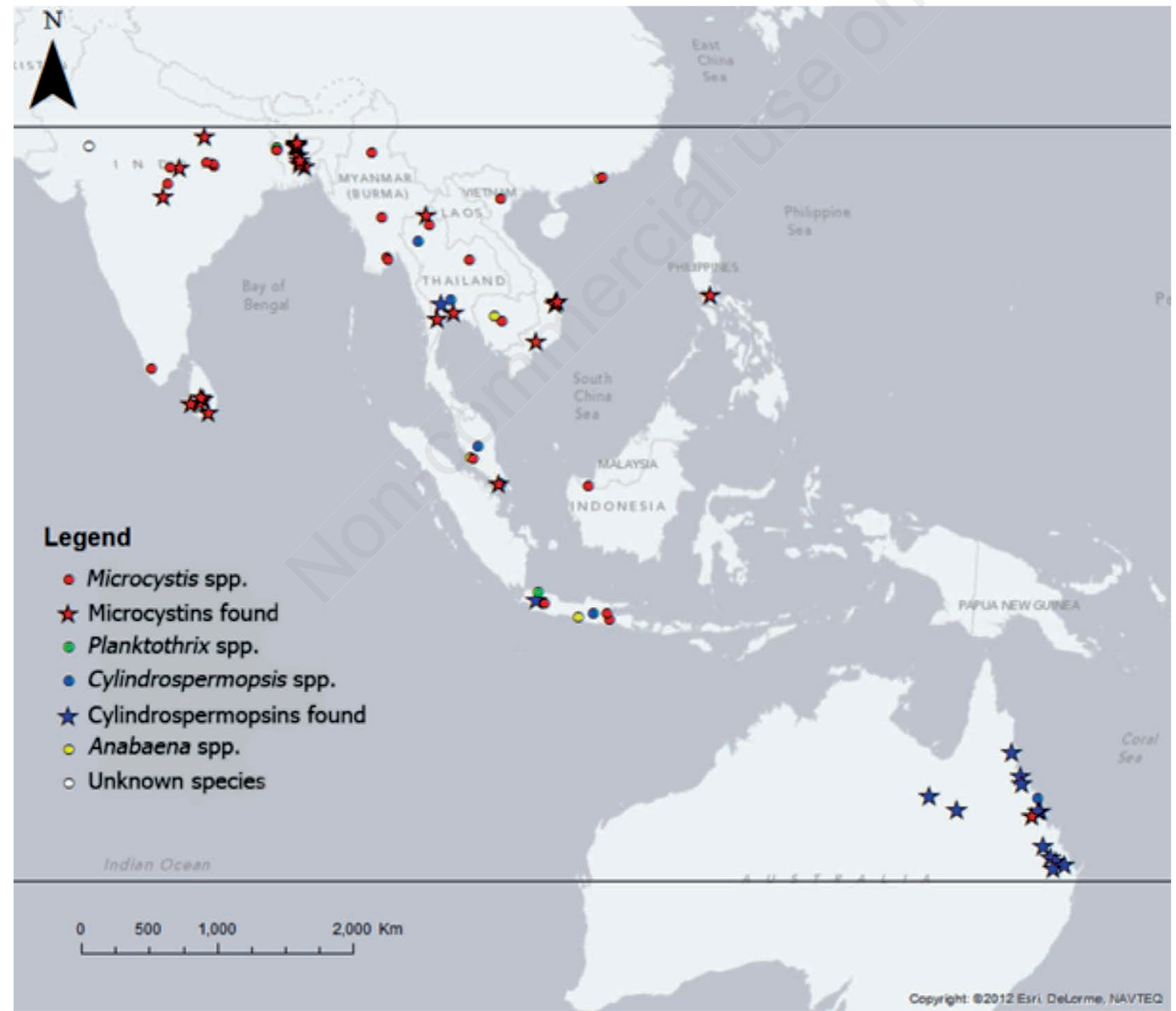

Fig. 4. Map of tropical Asia and Australia showing locations of cyanobacterial blooms, horizontal lines enclose the tropical region around the equator. 
drospermopsis raciborskii, although recent taxonomic revisions now recognise more than one species, e.g., coiled morphotypes of $C$. raciborskii are now known as $C$. philippinensis (Komárek and Mareš, 2011). Even though C. raciborskii has been bloom-forming in one country and commonly found in two others, cylindrospermopsin production of $1.02 \mathrm{mg} \mathrm{g}^{-1}$ was recorded from only one study in Thailand (Li et al., 2001). The toxin level of this strain was much lower than an Australian strain cultured in the same conditions (1.358 $\left.\mathrm{mg} \mathrm{g}^{-1}\right)$ (Li et al., 2001).

In contrast to tropical Asia, Cylindrospermopsis was the dominant bloom-forming genus in tropical Australia, accounting for seven out of eight blooms (Figs. 1 and 4; Tab. 1). C. raciborskii blooms from Palm Island were highly toxic with cylindrospermopsin levels of up to 20 $\mu \mathrm{g} \mathrm{L}^{-1}$ recorded (McGregor and Fabbro, 2000; Griffiths and Saker, 2003). Additionally, C. raciborskii blooms from Palm Island were strongly implicated in the severe hepatoenteritis poisoning of 149 people in 1979 (Hawkins et al., 1985).

\section{Tropical Africa}

Cylindrospermopsis blooms were the second most prevalent blooms in tropical Africa (Fig. 1). It was found in four out of eleven countries including Nigeria, Senegal, Uganda and Zimbabwe (Tab. 2; Fig. 3). The only species recorded was Cylindrospermopsis raciborskii; however, only strains from ponds in Nigeria were found to produce cylindrospermopsin (Odokuma and Isirima, 2007). Strains from Kazinga Channel, Uganda and Lake Guiers, Senegal were isolated and tested for toxins by LC-MS and mouse bioassay respectively, but were not found to produce any cylindrospermopsin and saxitoxins (Lake Guier isolates) (Haande et al., 2008; Berger et al., 2006).

\section{Tropical America}

Cylindrospermopsis was the most encountered bloom genus in the tropical Americas occurring in 47\% of all documented cyanobacterial blooms (Figs. 1 and 5). Three species were frequently encountered, C. raciborskii, $C$. catemaco and C. philippinensis (Tab. 3). These blooms were recorded from Brazil and Mexico (Fig. 5; Tab. 3). Saxitoxins (STX, NEO, GTX2 and GTX3) and cylindrospermopsins were produced by several strains of Cylindrospermopsis isolated from Brazil and Mexico (Bouvy et al., 1999; Molica et al., 2002; Molica et al., 2005; dos Anjos et al., 2006; Frias et al., 2006; Ferrão-Filho et al., 2007; Berry and Lind, 2010). The Cylindrospermopsis blooms in the tropical Americas differ from the Cylindrospermopsis strains isolated in Thailand and Australia, in that they produced saxitoxin in addition to cylindrospermopsins (Tabs. 1, 2 and 3).

\section{Other problem taxa}

\section{Anabaena}

Less than $7 \%$ of total blooms that occurred in tropical Asia were dominated by Anabaena spp. (Tab. 1, Fig. 4). These blooms were not tested for toxins, although a bloom of Anabaena flos-aquae in Bangladesh caused massive fish kills (Jewel et al., 2003). Anabaena blooms also occurred in Nigeria, Tanzania, Ghana, and Malawi (Tab. 2; Fig. 3). Microcystin variants were detected in raw water in Ghana containing A. flos-aquae and Microcystis aeruginosa, thus, toxin production could not be attributed specifically to A. flos-aquae (Addico et al., 2006). The only Anabaena sp. blooms that tested positive for anatoxin-a and anatoxin-a(s) occurred in Nigeria (Odokuma and Isirima 2007). In Tapacura Reservoir in Brazil, blooms of Anabaena spiroides co-dominated with Cylindrospermopsis raciborskii. Anabaena spiroides was found to produce anatoxin-a(s) and a mixed bloom sample of $C$. raciborskii and $A$. spiroides was found to contain saxitoxins (Stx and NeoStx) (Molica et al., 2005).

\section{Planktothrix}

Planktothrix blooms were found in four out of thirteen tropical Asian countries including Malaysia, Indonesia, Vietnam, Singapore and Thailand (Li et al., 2001; Merican et al., 2006; Nguyen et al., 2007b; Prihantini et al., 2008; Pham et al., 2011). Planktothrix agardhii, a possible toxin producing species, is currently known to form blooms in Indonesia and Brazil (Akcaalan et al., 2006; Moura et al., 2011). P. agardhii blooms in Carpina Reservoir, Brazil were found to co-dominate with $C$. raciborskii. These blooms were not tested for toxins, although some strains of $P$. agardhii can produce hepatotoxins (Janse et al., 2005).

Planktothrix zahidii was bloom-forming in Vietnam (Nguyen et al., 2007a). However, this species did not produce any microcystins. Toxin testing on other Planktothrix species in Malaysia, Indonesia, Singapore and Thailand has yet to be reported.

\section{Pseudanabaena}

While microcystins are mostly produced by Microcystis spp., one microcystin variant (MC-LR) was also produced by a strain of Pseudanabaena cf. moniliformis isolated in Vietnam (Tab. 1). This species was detected in lower concentrations in the reservoirs compared with $\mathrm{Mi}$ crocystis spp. Another species, Pseudanabaena mucicola, was also recorded in water bodies in Mexico and Brazil and Pseudanabaena sp. was recorded in Bangladesh (Welker et al., 2004; Frias et al., 2006; Vasconcelos et al., 2010). Toxin testing was carried out on water bodies in all three countries containing $P$. mucicola and Pseudanabaena sp., but the microcystin level could not be attributed to either species due to the presence of Microcystis 
spp. It is important to note that Pseudanabaena is similar in morphology to Cylindrospermopsis, thus, records of Pseudanabaena in Mexico, Brazil and Bangladesh (Welker et al., 2004; Frias et al., 2006; Vasconcelos et al., 2010), which did not include pictures and formal descriptions of Pseudanabaena species could not be verified, and might potentially be misidentifications.

\section{Arthrospira and Anabaenopsis}

Blooms of Arthrospira fusiformis and Anabaenopsis abijitae that produced anatoxin-a were recorded in the Kenyan rift lakes (Ballot et al., 2005; Odokuma and Isirima, 2007) (Tab. 2; Fig. 3). These species were otherwise not bloom-forming in any other tropical country.

\section{Lyngbya}

Lyngbya spp. blooms were recorded in Guatemala and Nigeria, with the species from Guatemala ( $L . h i-$ eronymusii, L. birgei, and L. robusta) producing saxitoxins and cylindrospermopsins and the species from Nigeria (Lyngbya sp.) producing only saxitoxins (Odokuma and Isirima, 2007; Rejmánková et al., 2011). These bloom-forming species were rare or absent in other tropical regions. The levels of cylindrospermopsin and saxitoxin recorded from Guatemala were relatively low (CYN: 0.6 to $1.2 \mathrm{ng} \mathrm{l}^{-1}$, STX: 2.9 to $5.8 \mathrm{ng} \mathrm{L}^{-1}$ ) and thus, do not appear to pose an immediate danger in water supplies. However, these blooms should be monitored for any changes in toxin production level (Rejmánková et al., 2011). The level of saxitoxins in blooms of Lyngbya sp. from the Sombreiro River in Nigeria was not quantified, and thus, warrants further testing to ascertain the level of saxitoxins present (Odokuma and Isirima, 2007).

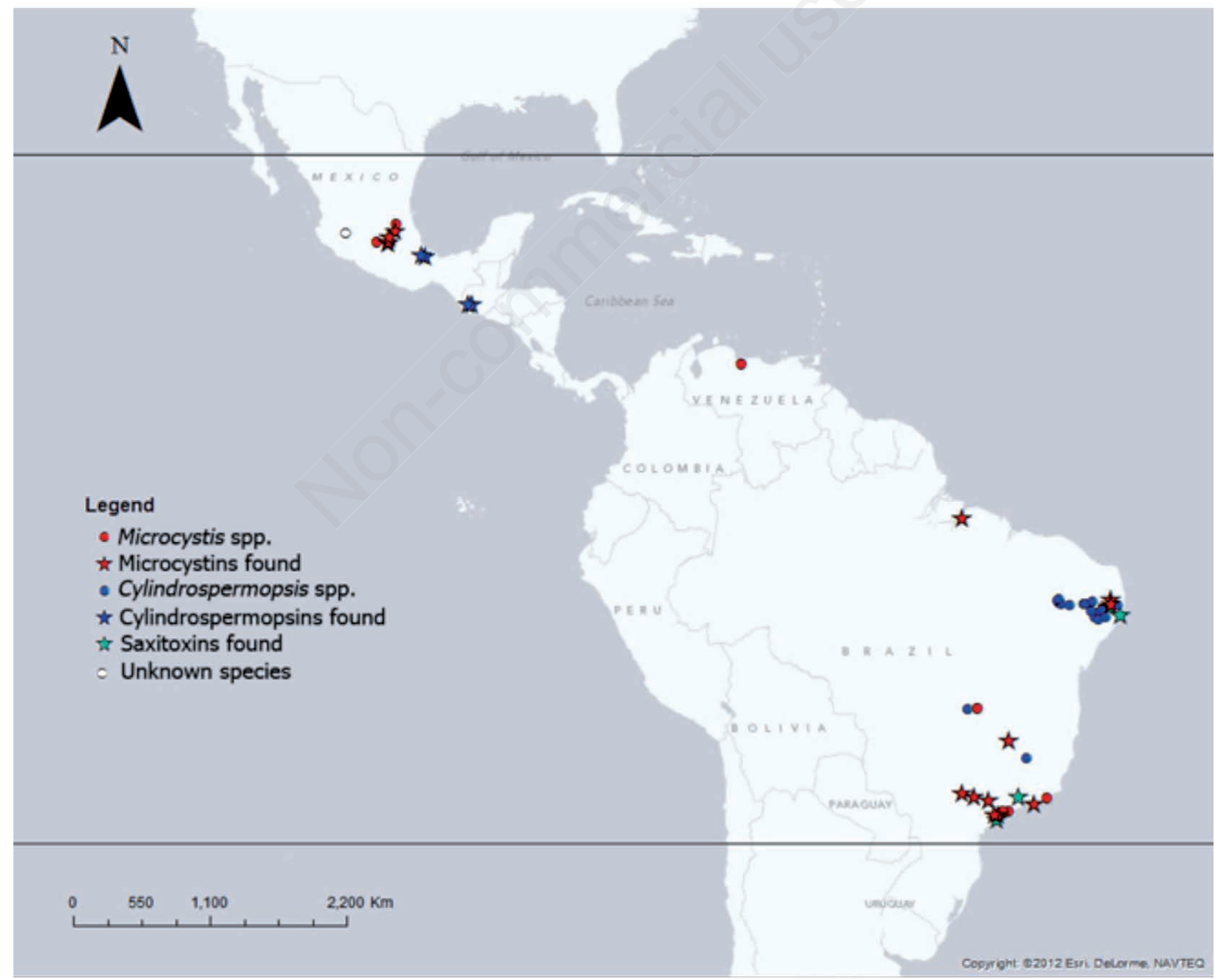

Fig. 5. Map of tropical America showing locations of cyanobacterial blooms, horizontal lines enclose the tropical region around the equator. 


\section{INFLUENCING ENVIRONMENTAL FACTORS FOR TOXIC CYANOBACTERIAL BLOOMS}

Many factors contribute to the occurrence of cyanobacterial blooms. Most cyanobacterial blooms in temperate regions occur in the summer when temperature, light and nutrient conditions are suitable for cyanobacterial dominance over other species in a lake phytoplankton community (Jöhnk et al., 2008; Davis et al., 2009). This predictability of cyanobacterial blooms in temperate regions allows preventive measures to be implemented to reduce their occurrence in water bodies used for potable purposes (Mitrovic et al., 2011). Tropical cyanobacterial blooms tend to be affected by temperature, nutrient input, and brief periods of drought and heavy rain (Bouvy et al., 2000; Baldia et al., 2003). Unlike temperate bloom events that occur in the warmer months and last for the entirety of the summer, tropical bloom events can occur at any time of the year and usually last for a few weeks at a time (Huszar et al., 2000; Figueredo and Giani, 2009; Prakash et al., 2009).

\section{Seasonality in the tropics}

Some water bodies in the tropics encounter a distinct seasonality in wet and dry periods, with some dry periods lasting several months (Figueredo and Giani, 2009). Nitrogen-fixing species were found to be bloom-forming during the dry season, due to strong thermal stratification and water column stability (Sprober et al., 2003). Since nitrogen fixing genera such as Anabaena and Cylindrospermopsis are able to fix atmospheric nitrogen for growth, these genera are able to compete in conditions of lower nitrogen,

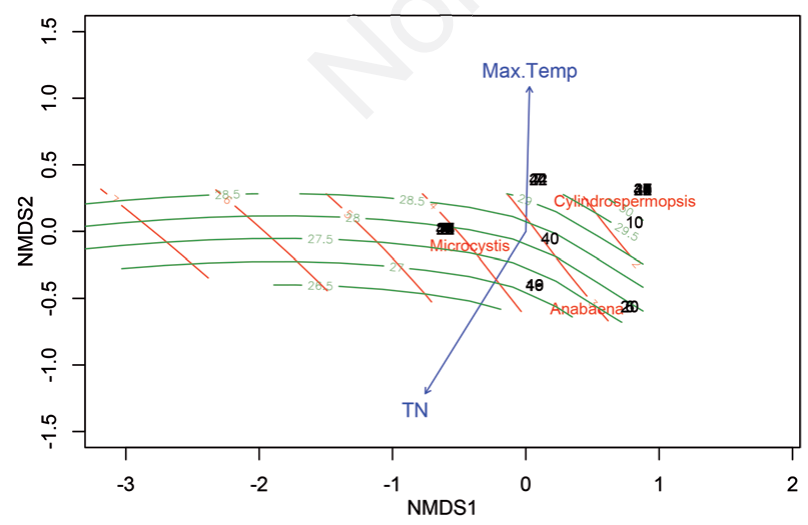

Fig. 6. Non-metric multidimensional scaling of tropical cyanobacterial blooms overlayed with maximum nitrogen levels and maximum temperatures (stress $<0.01$ ), arrows indicate nitrogen and temperature effects on bloom genera. Oblique lines represent smoothers connecting total nitrogen concentrations and intersecting lines represent smoothers connecting maximum temperature values. for example, after a long period of stratification (Khuantrairong et al., 2008; Bormans et al., 2004; Hawkins and Griffiths, 1993; Hawkins, 1985; Saker and Griffith, 2001; Komarek and Kling, 1991; Okechukwu and Ugwumba, 2008; Berger et al., 2006; Dufour et al., 2006; Gondwe et al., 2007; Branco and Senna, 1994; Bouvy et al., 1999; Bouvy et al., 2003; Vieira et al., 2005; Vieira et al., 2003). Some studies documented Microcystis blooms in the wet season due to elevated nutrient levels in the various water bodies, occurring after periods of heavy rainfall (Ochumba and Kibaara, 1989; Makahant et al., 1998; Salonen et al., 1999; Arfi et al., 2001; Kitaka et al., 2002; Wang et al., 2002; Welker et al., 2004; Sekandende et al., 2005; Meesuko et al., 2007; Krishnan, 2008; Onyema 2010; Sitoki et al., 2012). Although wet/dry seasonality in the tropics can contribute to cyanobacterial blooms, some water bodies with distinct dry and wet seasons do not show seasonality in cyanobacterial bloom occurrence (Figueredo and Giani, 2009; Werner and Laughinghouse, 2009; Frias et al., 2006; dos Anjos et al., 2006).

\section{Effects of nutrients and temperature on tropical blooms}

Based on the results of the NMDS, highest total nitrogen (TN) concentration was significantly related to the occurrences of specific cyanobacterial genera (Fig. 6) (Pvalue $=0.025^{*}<\mathrm{P}_{\text {critical }}=0.05$ ). Although total nitrogen was non-linearly associated with dominance of cyanobacterial genera, as seen from the surface fitting in Fig. 6, higher nitrogen levels were more associated with Microcystis blooms, while lower nitrogen levels were associated with Cylindrospermopsis blooms. Maximum temperature was also significantly related to cyanobacterial genera (Fig. 6) (P-value $=0.029 *<\mathrm{P}_{\text {critical }}=0.05$ ). Higher maximum temperature was more associated with Cylindrospermopsis blooms compared to Microcystis and Anabaena blooms (Fig. 6).

The results of this meta-analysis corroborates some findings from individual studies across all regions, which identify elevated total nitrogen concentrations as one of the more important factors in the development of tropical Microcystis blooms (Mahakhant et al., 1998; Huszar et al., 2000; Cuvin-Aralar et al., 2002; Welker et al., 2004; Jayatissa et al., 2006; Magadza, 2006; Ghosh et al., 2008; Chia et al., 2009; Rejmánková et al., 2011). Other factors such as high temperature do contribute to Microcystis bloom formation, however, the role of temperature was not as important as total nitrogen concentration (Fig. 6). Some studies have found that higher temperatures favour Cylindrospermopsis blooms (Bouvy et al., 2000; Huszar et al., 2000; Saker and Griffiths, 2001; Berger et al., 2006; Dufour et al., 2006; Ghosh et al., 2008; Figueredo and Giani, 2009), while high total nitrogen concentration may not be as important for Cylindrospermopsis bloom occurrence, due to the fact that Cylindrospermopsis are nitrogen-fixing 
cyanobacterial genera (Bouvy et al., 1999; Rustadi et al., 2002; Gondwe et al., 2007; Khuantrairong and Traichaiyaporn, 2008). Comparing this outcome to temperate areas, Cylindrospermopsis blooms in France are similarly affected by high temperature (Briand et al., 2002). Higher temperatures were found to be a key factor in germination of akinetes (Briand et al., 2002). However, it is important to note that a combination of these factors, and not a single factor alone, usually leads to the development of a bloom (Paerl et al., 2001; Jacoby et al., 2003).

Highest total phosphorus concentration was found to be non-significant $\left(\mathrm{P}-\right.$ value $\left.=0.669 \cdot>\mathrm{P}_{\text {critical }}=0.05\right)$ in relation to the genera of bloom-forming cyanobacteria from the tropics in this meta-analysis. This could be due to the fact that TN:TP ratios were below 23:1 in most studies surveyed indicating non-limiting phosphorus conditions according to Guildford and Hecky (2000) and thus, the highest total phosphorus did not have any significant effect on the genera of bloom-forming cyanobacteria.

The ratios of total nitrogen:total phosphorous (TN:TP) were also found to be non-significant ( $\mathrm{P}$-value $=0.832>$ $\left.\mathrm{P}_{\text {critical }}=0.05\right)$ in relation to genera of bloom-forming cyanobacteria. This surprising outcome may not necessarily be due to the reduced importance of TN:TP in determining cyanobacterial dominance, but in the lack of long-term data present in the papers selected for the analysis. In temperate lakes, low TN:TP and stable water conditions have been shown to lead to the dominance of both nitrogen and non-nitrogen-fixing cyanobacteria (Smith et al., 1983). However, as noted by Paerl et al. (2001), TN:TP ratios may have less of an effect when total nitrogen and total phosphorous are not limiting, which seems to be the case for most tropical lakes and reservoirs in the analysis.

Another factor that has been known to affect the dominance of cyanobacterial bloom species is the type of water body (Dokulil and Teubner, 2000). In temperate regions, large shallow lakes such as Lake Taihu in China are conducive to Microcystis blooms, while deeper, wellmixed lakes in France are conducive to Cylindrospermopsis blooms, and deep, alpine lakes are favourable to Planktothrix blooms (Dokulil and Teubner, 2000). There were three main types of water bodies in the present metadata, natural lakes, artificial reservoirs, and ponds. There was a significant difference in bloom genera between lakes and reservoirs (Fig. 7, P-value $=0.001 *<0.05$ ), with Microcystis blooms found in more natural lakes than reservoirs and Cylindrospermopsis blooms found in more reservoirs than natural lakes, as indicated in Fig. 7 by the clear separation between two ellipses. This could be due to the difference in structure of tropical lakes and reservoirs. Natural lakes usually discharge surface water but reservoirs can have outlets at different depths and thus, this may affect the outflow of the water body (Ji, 2008). Most reservoirs may encounter extreme fluctuations in water level depending on water usage, while natural lakes tend to have less extreme fluctuations in water level and very little control of discharge depth (Ji, 2008). Greater mixing and higher turbidity of the mixed layer in reservoirs and could lead to more Cylindrospermopsis blooms, especially in times of drought (Bouvy et al., 2000). Stable water conditions and limited changes in discharge depths combined with high nutrients may lead to a higher occurrence of Microcystis blooms in natural lakes (Baldia et al., 2003). However, it is important to note that the studies used in this meta-analysis may not be representative of all tropical lakes and reservoirs. The effect of ponds could not be discerned in this analysis, as there was only one pond out of the 48 water bodies selected. However, similar genera were present in this pond compared to the other water body types.

Other factors such as light intensity and stratification of the lakes were not taken into account for this meta-analysis due to the lack of detailed information on light and temperature profiles of the water bodies. Flushing of water bodies was not analysed in this meta-analysis due to the lack of detailed information for flushing rates of different water bodies. Poste et al. (2013) showed that higher flushing rates of Napolean Gulf in Lake Victoria had led to a lower biomass of Microcystis compared to other less flushed sites such as Lake George and Lake Saka in Uganda. However, the rate of flushing and difference in biomass was not quantified and thus, higher flushing in combination with other factors may have caused the lower biomass of Microcystis. Jayatissa et al. (2006) did note a decrease in cyanobacterial blooms in Sri Lanka due to flushing and dilution of water after heavy rains. However, this study noted that cell density of Micro-

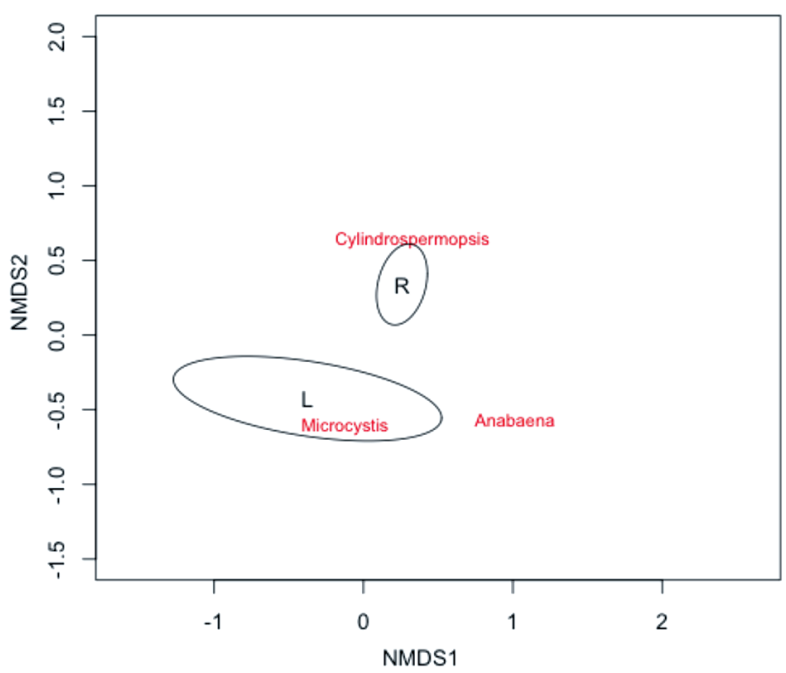

Fig. 7. Non-metric multidimensional scaling of tropical cyanobacterial blooms overlayed with ellipses indicating types of water bodies (L, lakes; R, reservoirs; P-value $=0.001 ; *<0.05$ ). 
cystis remained high even without scum formation throughout the wet and dry seasons. Retention time was indicated as an important variable in determining the biomass of cyanobacteria in Funil Reservoir in Brazil (Soares et al., 2012). In Barra Bonita reservoir, cyanobacterial biomass was recorded during both short and long retention times and in highly stratified and destratified conditions, indicating that nutrient availability was more important than flushing (Dellamano-Oliveira et al., 2008). Overall, flushing and retention time of a tropical reservoir may be important in determining biomass in the surface water, however, nutrients may play a larger role in determining biomass growth in the entire water body throughout the year.

\section{Effects of nutrient levels on microcystin production}

Nitrogen concentration was found to be one of the more important factors influencing tropical Microcystis bloom formation (Fig. 6). Cyanobacterial blooms in tropical countries occurred over a wide range of N:P ratios. The N:P values found in tropical lakes with the highest microcystin values appear to be similar to those in temperate lakes at approximately 20 (Orihel et al., 2012) (Fig. 8). It was found that as N:P (nitrate:phosphate) values increased, the level of microcystins increased significantly (Spearman's rank correlation, $\rho=0.746$, $\mathrm{P}$-value $=0.002<\mathrm{P}_{\text {crit }} 0.05$ ) for microcystin levels higher than $1 \mu \mathrm{g} \mathrm{L}^{-1}$ (R Core Team 2012) (Fig. $8)$. There are distinct geographical patterns present in the level of N:P (nitrate:phosphate) and microcystins encountered in the tropics, with African blooms having lower microcystin values and $\mathrm{N}: \mathrm{P}$ (nitrate:phosphate) ratios recorded compared to blooms in Asia and Australia (Fig. 8). This could be due to an artefact in the timing of the data collection (snapshot data vs long term data) and not purely due

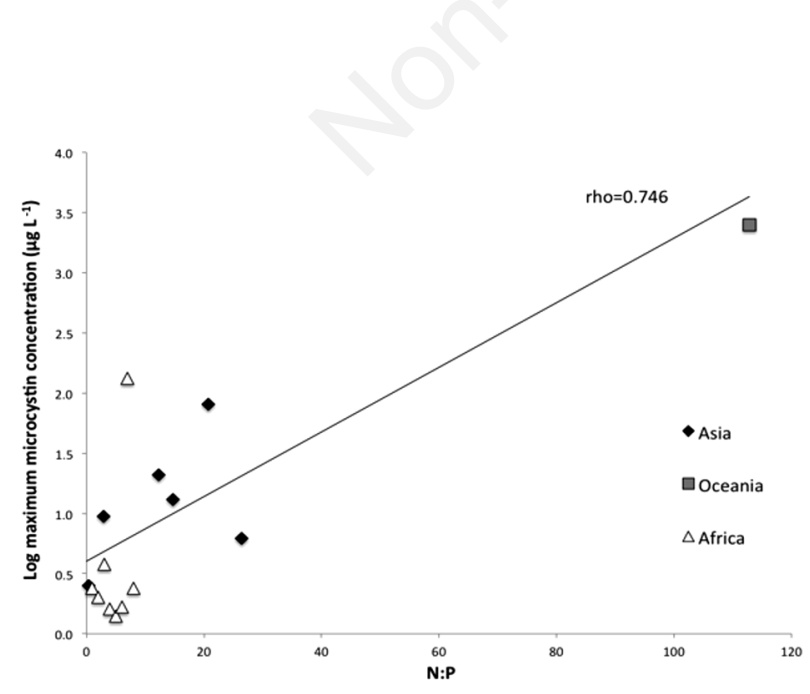

Fig. 8. $\log$ maximum microcystin concentrations $\left(\mu \mathrm{g} \mathrm{L}^{-1}\right)$ at different N:P values in tropical lakes and reservoirs. Cyanobacterial blooms with less than $1 \mu \mathrm{g} \mathrm{L}^{-1}$ of microcystin recorded were not included in this analysis. to a lower N:P (nitrate:phosphate) ratio present in African water bodies (Chia et al., 2009). However, it is important to note that the data analysed were taken from studies that documented microcystin concentration as well as nitrate and phosphate levels. Some studies that documented high microcystin concentrations ( $>3 \mu \mathrm{g} \mathrm{L}^{-1}$; Addico et al., 2006) did not document nitrate or phosphate levels and thus could not be taken into account for this analysis. Also, studies that documented the presence of microcystins without quantification could not be accounted for (Odokuma and Isirima, 2007; Haande et al., 2007).

However, it is important to note that the $\mathrm{N}: \mathrm{P}$ (nitrate:phosphate) ratio alone is not the only factor influencing the level of microcystin production by cyanobacteria. Different strains and species of microcystin-producing cyanobacteria respond differently to individual changes in concentrations of nitrogen and phosphorus (de Figueiredo et al., 2004). The data on nutrient levels in tropical lakes and reservoirs are also sparse and thus the relationship between N:P (nitrate:phosphate) ratios and microcystin production in tropical countries cannot be fully explored. Different species and strains of cyanobacteria can also have differing levels of microcystin production based on other factors such as temperature.

\section{Effect of temperature on microcystin concentration}

Increased temperatures in temperate countries can lead to more toxic strains developing and outcompeting nontoxic strains of Microcystis (Briand et al., 2008; Davis et al., 2009). The higher gene copy of microcystin synthetase genes (McyD) in Microcystis species at elevated temperatures could mean increased toxicity of cyanobacterial blooms under warmer conditions (Davis et al., 2009). However, this trend has yet to be found in tropical water bodies and Spearman's correlation analysis on the maximum temperatures of water bodies and total microcystin concentration based on 11 papers and 17 water bodies, did not yield significant results $\left(\rho=0.318\right.$, $P$-value $\left.=0.229>P_{\text {crit }} 0.05\right)$. Studies that did not document the maximum temperatures for individual water bodies were excluded and thus, there is a certain bias in the results that could have led to this insignificant effect of temperature. However, temperature ranges in the tropics are within $1-8^{\circ} \mathrm{C}$ for each water body (Ahmed et al., 2008; Wang et al., 2002; White et al., 2003; Kotut et al., 2010) and this small increase in temperature, which was within the optimum temperature range of Microcystis toxin production $\left(25-30^{\circ} \mathrm{C}\right.$, Van der Westhuizen and Eloff, 1985; Kim et al., 2005), may not significantly affect toxicity.

\section{Effect of microcystis biomass on microcystin concentration}

The concentration of cyanobacteria may also influence microcystin levels. Studies in temperate, sub-tropical as 
well as tropical countries have found positive correlations between the concentration of microcystin and the concentration of cyanobacteria in blooms (Xu et al., 2008; Poste et al., 2013). Our analysis across tropical American and Asian regions also showed microcystins to significantly increase (Spearman's rank correlation, $\rho=0.94$, Pvalue $=0.017^{*}<\mathrm{P}_{\text {crit }} 0.05$ ) with increasing concentration of Microcystis spp. (R Core Team, 2012) (Fig. 9). However, this trend was clear only for toxin concentrations higher than $1 \mu \mathrm{g} \mathrm{L}^{-1}$. Concentrations of blooms from tropical American and Asian countries containing known toxic strains of cyanobacteria can possibly be used to estimate microcystin levels in areas where regular toxin testing is unavailable or unaffordable. This correlation was not significant for tropical African blooms (Spearman's rank correlation, $\rho=0.373$, P-value $=0.153>\mathrm{P}_{\text {crit }} 0.05$ ), where tropical African blooms had lower microcystin concentration per cell concentration as compared to tropical Asian and American blooms (Fig. 9). The lower microcystin concentration per cell in African lakes was based
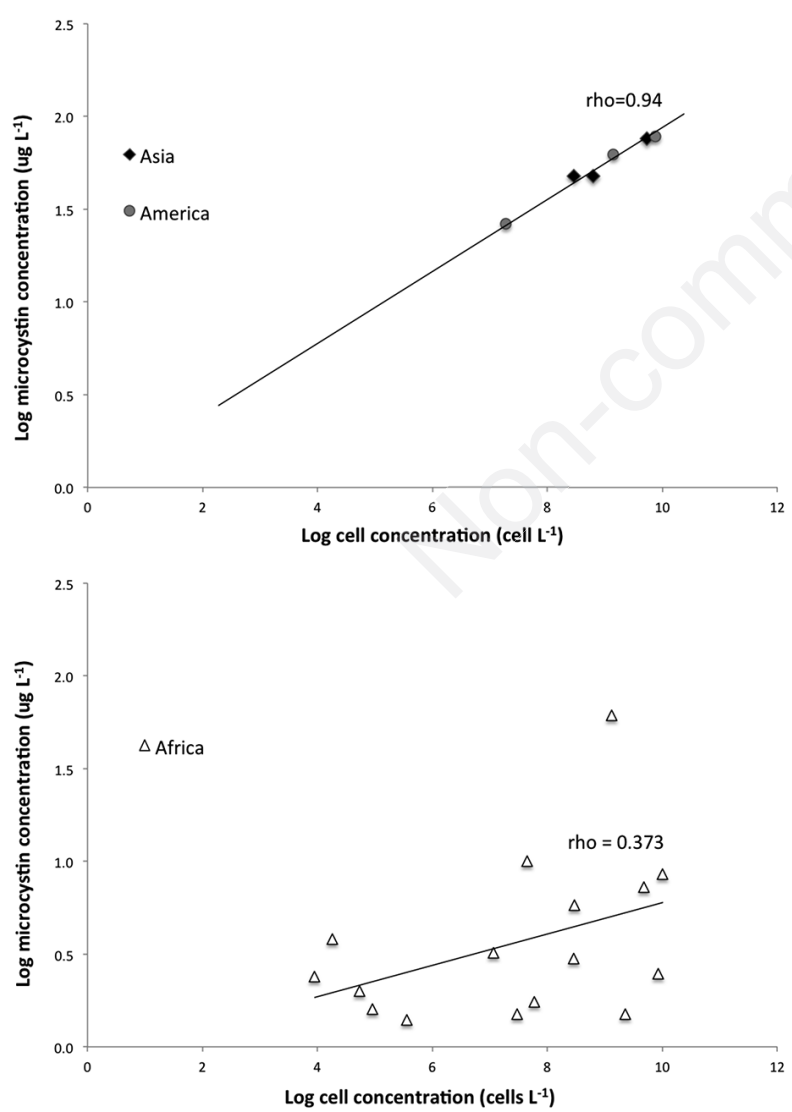

Fig. 9. Log microcystin concentrations $\left(\mu \mathrm{g} \mathrm{L}^{-1}\right)$ plotted against log cell abundance (cells $\mathrm{L}^{-1}$ ) for different cyanobacterial blooms in the tropics. Cyanobacterial blooms with less than $1 \mu \mathrm{g} \mathrm{L}{ }^{-1}$ of microcystin recorded were not included in this analysis. on a limited amount of studies and could be a result of the infrequent sampling and short time periods sampled (monthly for 1 year, Okello et al., 2010; monthly for 6 months, Poste et al., 2013). Data collected bimonthly and over a longer period of time should be more indicative of the trends. Also, Okello et al. (2011) found that there was significant within site variation of microcystin production per Microcystis cell for lakes in Uganda and that average microcystin per cell was dependent on the proportion of $m c y B$ genotype of Microcystis more than direct cell counts. However, this trend was not clear in other tropical water bodies. Vasconselos et al. (2010) indicated that even though $m c y B$ was present in a Mexican lake sample, there was zero microcystins detected and similarly, another lake that had zero $m c y B$ detected, had microcystins detected. Thus, there is no clear indicator of microcystin content in water bodies across the tropics but each water body should have its own guideline for either $m c y B$ genotypes or Microcystis cells, depending on which factor has better predictive power. The variation of microcystin production by Microcystis has also been noted in temperate blooms where time and location were important factors in determining microcystin production within a connected freshwater ecosystem (Sabart et al., 2010). Another important note about this correlation analysis is that it was based on a limited number of studies and water bodies and in order to improve its applicability and context, more studies with higher frequency of sampling over longer periods of time should be added.

\section{CONCLUSIONS}

It is important to understand the prevailing patterns or trends of toxic cyanobacterial blooms in the tropics as these may differ from the more widely studied temperate and subtropical regions. Across the tropics, the genus $\mathrm{Mi}$ crocystis was the most prevalent bloom-forming cyanobacteria, followed by Cylindrospermopsis, with fewer blooms formed by Anabaena and Planktothrix. However, different tropical regions were also characterized by different bloom-forming species such as Cylindrospermopsis spp. being more prevalent in tropical Australia and Brazil, and Microcystis spp. more so in Asia, Africa and Central America. Microcystins were the most frequently encountered toxins, while cylindrospermopsins, anatoxins and saxitoxins were detected in fewer water bodies in tropical areas.

Various studies showed that Cylindrospermopsis blooms were more likely to occur in the dry season as compared to the wet season in the tropics while Microcystis blooms were found to bloom during the wet season after heavy rain.

Based on our meta-analysis, increasing total nitrogen levels were related to more Microcystis blooms and higher maximum temperatures were associated with more Cylin- 
drospermopsis blooms. Tropical lakes were significantly associated with Microcystis blooms while tropical reservoirs were significantly associated with Cylindrospermopsis blooms. Microcystin levels from Microcystis blooms were found to have a positive relationship with N:P (nitrate:phosphate) ratios across the tropics. Tropical African blooms were found to have no significant correlation between microcystin concentration and cell concentration as compared to Asian and American blooms, which showed significant positive correlation between microcystin concentration and cell concentration. Concentrations of blooms from tropical Asian and American countries containing known toxic strains of cyanobacteria can possibly be used to estimate microcystin levels in areas where regular toxin testing is unavailable or unaffordable. Maximum temperature of tropical water bodies did not have a significant effect on total microcystin concentrations, which may be due to the warmer temperatures experienced being within the optimum temperature range for microcystin production.

Although, the results from our meta-analysis and correlation analysis agree with the general literature on cyanobacterial blooms, it is important to note that all the analyses were based on small subsets of the total literature found on tropical countries, and that there were many water bodies without information that were not included. There could also be possible bias of data due to low frequency of sampling and short sampling duration in several studies. Thus, more information about cyanobacterial blooms in tropical countries is still needed to gain further insights into their patterns of occurrence, toxin production and causes of blooms.

\section{ACKNOWLEDGMENTS}

Funding support for this study was provided by a research grant from the Public Utilities Board of Singapore (National University of Singapore Grant No. R-154-000523-490), an AcRF Tier 1 grant from the Singapore Ministry of Education (National University of Singapore Grant No. R-154-000-465-133), and the National University of Singapore Industrial Postgraduate Program. The authors would like to thank Karina Gin (NUS), Low EWen (PUB) and Alex Yee (NUS) for their valuable help and feedback on the manuscript.

\section{REFERENCES}

Addico G, Hardege J, Komarek J, Babica P, de Graft-Johnson KAA, 2006. Cyanobacteria species identified in the Weija and Kpong reservoirs, Ghana, and their implications for drinking water quality with respect to microcystin. Afr. J. Mar. Sci. 28:451-456.

Agrawal MK, Ghosh SK, Bagchi D, Weckesser J, Erhard M, Bagchi S, 2006. Occurrence of microcystin-containing toxic water blooms in Central India. J. Microbiol. Biotechn. 16:212-218.
Ahmed MS, Hiller S, Luckas B, 2008. Microcystis aeruginosa bloom and the occurrence of microcystins (Heptapeptides Hepatotoxins) from an aquaculture pond in Gazipur, Bangladesh. Turk. J. Fish. Aquat. Sc. 8:37-41.

Ahmed MS, Luckas B, 2008. Microcystis aeruginosa (Chroococcales, Cyanobacteria) bloom and the occurrence of microcystins in a freshwater pond in Bangladesh. Journal for Centre for Development of Research 4:135-141.

Ajuzie CC, 2012. A first survey of phytoplankton community richness in Lamingo Reservoir, Jos, Nigeria: A wake-up call for the continuous monitoring of microalgae in surface waters serving as drinking water sources in Nigeria. New York Sci. J. 5:1-8

Akcaalan R, Young FM, Metcalf JS, Morrison LF, Albay M, Codd GA, 2006. Microcystin analysis in single filaments of Planktothrix spp. in laboratory cultures and environmental blooms. Water Res. 40:1583-1590.

Akin-Oriola GA, 2003. On the phytoplankton of Awba reservoir, Ibadan, Nigeria. Rev. Biol. Trop. 51:1-6.

Akin-Oriola GA, Anetekhai MA, Oriola A, 2006. Algal blooms in Nigerian waters: an overview. Afr. J. Mar. Sci. 28:219-224.

Anadu DI, Obiaha A, Ejike C, 1990. Water quality and plankton periodicity in two contrasting mine lakes in Jos, Nigeria. Hydrobiologia 208:17-25.

Arfi R, Bouvy M, Cecchi P, Pagnao M, Thomas S, 2001. Factors limiting phytoplankton productivity in 49 shallow reservoirs of North Côte d'Ivoire (West Africa). Aquat. Ecosyst. Health 4:123-138.

Azevedo SMFO, Carmichael WW, Jochimsen EM, Rinehart KL, Lau S, Shaw GR, Eaglesham GK, 2002. Human intoxication by microcystins during renal dialysis treatment in CaruaruBrazil. Toxicology 181:441-446.

Baldia SF, Conaco MCG, Nishijima T, Imanishi S, Harada KI, 2003. Microcystin production during algal bloom occurrence in Laguna de Bay, the Philippines. Fisheries Sci. 69:110-116.

Baldia SF, Evangelista AD, Aralar EV, Santiago AE, 2007. Nitrogen and phosphorus utilization in the cyanobacterium $\mathrm{Mi}$ crocystis aeruginosa isolated from Laguna de Bay, Philippines. J. Appl. Phycol. 19:607-613.

Ballot A, Krienitz L, Kotut K, Wiegand C, Pflugmacher S, 2005. Cyanobacteria and cyanobacterial toxins in the alkaline crater lakes Sonachi and Simbi, Kenya. Harmful Algae 4:139-150.

Bartram J, Burch M, Falconer IR, Jones G, Kuiper-Goodman T, 1999. Situation assessment, planning and management, $\mathrm{p}$. 183-210. In: I. Chorus and J. Bartram (eds.), Toxic cyanobacteria in water. Taylor and Francis.

Beasley VR, Dahlem AM, Cook WO, Valentine WM, Lovell RA, Hooser SB, Harada K-I, Suzuki M, Carmichael WW, 1989. Diagnostic and clinically important aspects of cyanobacterial (blue-green algae) toxicoses. J. Vet. Diagn. Invest. 1:359-365.

Berger C, Ba N, Gugger M, Bouvy M, Rusconi F, Coute A, Troussellier M, Bernard C, 2006. Seasonal dynamics and toxicity of Cylindrospermopsis raciborskii in Lake Guiers (Senegal, West Africa). Microb. Ecol. 57:355-366.

Bernard C, Harvey M, Briand JF, Biré R, Krys S, Fontaine JJ, 2003. Toxicological comparison of diverse Cylindrospermopsis raciborskii strains: evidence of liver damage caused by a french C. raciborskii strain. Environ. Toxicol. 18:176-186.

Berry JP, Lind O, 2010. First evidence of "paralytic shellfish 
toxins" and cylindrospermopsin in a Mexican freshwater system, Lago Catemaco, and apparent bioaccumulation of the toxins in "tegogolo" snails (Pomacea patula catemacensis). Toxicon 55:930-938.

Bittencourt-Oliveira MC, 2003. Detection of potential microcystin-producing cyanobacteria in Brazilian reservoirs with a mcyB molecular marker. Harmful Algae 2:51-60.

Bittencourt-Oliveira MC, Kujbida P, Cardozo KHM, Carvalho VM, Moura AdN, Colepicolo P, Pinto E, 2005. A novel rhythm of microcystin biosynthesis is described in the cyanobacterium Microcystis panniformis Komárek et al. Biochem. Bioph. Res. Co. 326:687-694.

Bittencourt-Oliveira MC, Oliveira MC, Pinto E, 2011. Diversity of microcystin-producing genotypes in Brazilian strains of Microcystis (Cyanobacteria). Braz. J. Biol. 71:209-216.

Bormans M, Ford PW, Fabbro LD, 2004. Spatial and temporal variability in cyanobacterial populations controlled by physical processes. J. Plankton Res. 27:61-70.

Bouvy M, Arfi R, Cecch P, Corbin D, Pagano M, Saint-Jean L, Thomas S, 1998. Trophic coupling between bacterial and phytoplanktonic compartments in shallow tropical reservoirs (Ivory Coast, West Africa). Aquat. Microb. Ecol. 15:25-37.

Bouvy M, Ba N, Ka S, Sane S, Pagano M, Arfi R, 2006. Phytoplankton community structure and species assemblage succession in a shallow tropical lake (Lake Guiers, Senegal). Aquat. Microb. Ecol. 45:147-161.

Bouvy M, Falcão D, Marinho M, Pagano M, Moura A, 2000. Occurrence of Cylindrospermopsis (Cyanobacteria) in 39 Brazilian tropical reservoirs during the 1998 drought. Aquat. Microb. Ecol. 23:13-27.

Bouvy M, Molica RJR, Oliveira SD, Marinho M, Beker B, 1999. Dynamics of a toxic cyanobacterial bloom (Cylindrospermopsis raciborskii) in a shallow reservoir in the semi-arid region of northeast Brazil. Aquat. Microb. Ecol. 20:285-297.

Bouvy M, Nascimento SM, Molica RJR, Ferreira A, Huszar V, Azevedo SMFO, 2003. Limnological features in Tapacurá reservoir (northeast Brazil) during a severe drought. Hydrobiologia 493:115-130.

Branco CW, Senna PA, 1994. Factors influencing the development of Cylindrospermopsis raciborskii and Microcystis aeruginosa in the Paranoa Reservoir, Brasilia, Brazil. Algological Studies 75:85-96.

Briand JF, Robillot C, Quiblier-Lloberas C, Humbert JF, Couté A, Bernard C, 2002. Environmental context of Cylindrospermopsis raciborskii (Cyanobacteria) blooms in a shallow pond in France. Water Res. 36:3183-3192.

Briand JF, Jacquet S, Bernard C, Humbert JF, 2003. Health hazards for terrestrial vertebrates from toxic cyanobacteria in surface water ecosystems. Vet. Res. 34:361-377.

Briand E, Yepremian C, Humbert JF, Quiblier C, 2008. Competition between microcystin- and non-microcystin-producing Planktothrix agardhii (cyanobacteria) strains under different environmental conditions. Environ. Microbiol. 10:3337-3348.

Campbell IC, Poole C, Giesen W, Valbo-Jorgensen J, 2006. Species diversity and ecology of Tonle Sap Great Lake, Cambodia. Aquat. Sci. 68:355-373.

Carmichael WW, 1996. Liver failure and human deaths at a haemodialysis centre in Brazil: microcystins as a major contributing factor. Harmful Algae News 15:11-12.

Carmichael WW, Azevedo SMFO, An JS, Molica RJR, Jochim- sen EM, Lau S, Rinehart KL, Shaw GR, Eaglesham GK, 2001. Human fatalities from cyanobacteria: Chemical and biological evidence for cyanotoxins. Environ. Health Persp. 109:663-668.

Chen J, Xie P, Li L, Xu J, 2009. First identification of the hepatotoxic microcystins in the serum of a chronically exposed human population together with indication of hepatocellular damage. Toxic. Sci. 108:81-89.

Chia AM, Abolude DS, Ladan Z, Kalaboms A, 2009. The presence of microcystins in aquatic ecosystems in Northern Nigeria: Zaria as a case study. Res. J. Env. Toxic. 3:170-178.

Cox PA, Banack SA, Murch SJ, Rasmussen U, Tien G, Bidigare RR, Metcalf JS, Morrison LF, Codd GA, Bergman B, 2005. Diverse taxa of cyanobacteria produce beta-N-methylaminoL-alanine, a neurotoxic amino acid. P. Natl. Acad. Sci. USA 102:5074-5078.

Cuvin-Aralar ML, Fastner J, Focken U, Becker K, Aralar EV, 2002. Microcystins in natural blooms and laboratory cultured Microcystis aeruginosa from Laguna de Bay, Philippines. Syst. Appl. Microbiol. 25:179-182.

Dao TS, Cronberg G, Nimptsch J, Do-Hong L-C. Wiegand C, 2010. Toxic cyanobacteria from Tri An Reservoir, Vietnam. Nova Hedwigia 90:433-448.

Davis TW, Berry DL, Boyer GL, Gobler CJ, 2009. The effects of temperature and nutrients on the growth and dynamics of toxic and non-toxic strains of Microcystis during cyanobacteria blooms. Harmful Algae 8:715-725.

de Figueiredo DR, Azeiteiro UM, Esteves SM, Goncalves FJ, Pereira MJ, 2004. Microcystin-producing blooms - a serious global public health issue. Ecotox. Environ. Safe. 59:151-163.

Dellamano-Oliveira MJ, Vieira AAH, Rocha O, Colombo V, Sant-Anna CL, 2008. Phytoplankton taxonomic composition and temporal changes in a tropical reservoir. Fund. Appl. Limnol. 171:27-38.

Díaz-Pardo E, Vazquez G, López-López E, 1998. The phytoplankton community as a bioindicator of health conditions of Atezca Lake, Mexico. Aquat. Ecosyst. Health 1:257-266.

Dokulil MT, Teubner K, 2000. Cyanobacterial dominance in lakes. Hydrobiologia 438:1-12.

Domingos P, Rubim TK, Molica RJR, Azevedo SMFO, Carmichael WW, 1999. First report of microcystin production by picoplanktonic cyanobacteria Isolated from a Northeast Brazilian drinking water supply. Environ. Toxicol. 14:31-35.

Dorr FA, Pinto E, Soares RM, Azevedo SMFO, 2010. Microcystins in South American aquatic ecosystems: Occurrence, toxicity and toxicological assays. Toxicon 56:1247-1256.

dos Anjos FM, Bittencourt-Oliveira C, Zajac MP, Hiller S, Christian B, Erler K, Luckas B, Pinto E, 2006. Detection of harmful cyanobacteria and their toxins by both PCR amplification and LC-MS during a bloom event. Toxicon 48:239-245.

Dufour P, Sarazin G, Quiblier C, Sane S, Leboulanger C, 2006. Cascading nutrient limitation of the cyanobacterium Cylindrospermopsis raciborskii in a Sahelian lake (North Senegal). Aquat. Microb. Ecol. 44:219-230.

Ezra AG, Nwankwo DI, 2001. Composition of phytoplankton algae in Gubi reservoir, Bauchi, Nigeria. J. Aquat. Sci. 16:115-118.

Falconer IR, 2008. Health Effects associated with controlled exposures to cyanobacterial toxins, p. 607-612 In: H. K. Hud- 
nell (ed.), Cyanobacterial harmful algal blooms. Springer.

Ferrão-Filho A, da Costa S, Ribeiro MGL, Azevedo SMFO, 2007. Effects of a saxitoxin-producer strain of Cylindrospermopsis raciborskii (Cyanobacteria) on the swimming movements of cladocerans. Environ. Toxicol. 23:161-168.

Figueredo CC, Giani A, 2009. Phytoplankton community in the tropical lake of Lagoa Santa (Brazil): Conditions favoring a persistent bloom of Cylindrospermopsis raciborskii. Limnologica 39:264-272.

Francis G, 1878. Poisonous Australian lake. Nature 18:11-12.

Frias HV, Mendes MA, Cardozo KH, Carvalho VM, Tomazela D, Colepicolo P, Pinto E, 2006. Use of electrospray tandem mass spectrometry for identification of microcystins during a cyanobacterial bloom event. Biochem. Biophy. Res. Co. 344:741-746.

Ganf GG, 1974. Phytoplankton biomass and distribution in a shallow eutrophic lake (Lake George, Uganda). Oecologia 16:9-29.

Ghosh SK, Das PK, Bagchi SN, 2008. PCR-based detection of microcystin-producing cyanobacterial blooms from Central India. Indian J. of Experimental Biol. 46:66-70.

Gondwe MJ, Guildford SJ, Hecky RE, 2007. Planktonic nitrogen fixation in Lake Malawi/Nyasa. Hydrobiologia 596:251-267.

Green J, Corbet SA, Watts E, Lan OB, 1976. Ecological studies on Indonesian lakes. Overturn and restratification of Ranu Lamongan. J. Zool. 180:315-354.

Green J, Corbet SA, Watts E, Lan OB, 1978. Ecological studies on Indonesian lakes. The montane lakes of Bali. J. Zool. $186: 15-38$.

Green J, 2010. Geographical variation in rotifers associated with Microcystis blooms. Hydrobiologia 662:197-204.

Gremberghe I, Gucht K, Vanormelingen P, Asmelash T, Dejenie T, D'hondt S, Declerck S, Meester L, Vyverman W, 2011. Genetic diversity of Microcystis blooms (Cyanobacteria) in recently constructed reservoirs in Tigray (Northern Ethiopia) assessed by rDNA ITS. Aquat. Ecol. 45:289-306.

Griffiths DJ, Saker ML, 2003. The Palm Island mystery disease 20 years on: a review of research on the cyanotoxin cylindrospermopsin. Environ. Toxicol. 18:78-93.

Guildford SJ, Hecky RE, 2000. Total nitrogen, total phosphorus, and nutrient limitation in lakes and oceans: Is there a common relationship? Limnol. Oceanogr. 45:1213-1223.

Haande S, Ballot A, Rohrlack T, Fastner J, Wiedner C, Edvardsen B, 2007. Diversity of Microcystis aeruginosa isolates (Chroococcales, Cyanobacteria) from East-African water bodies. Arch. Mikrobiol. 188:15-25.

Haande S, Rohrlack T, Ballot A, Røberg K, Skulberg R, Beck M, Wiedner C, 2008. Genetic characterisation of Cylindrospermopsis raciborskii (Nostocales, Cyanobacteria) isolates from Africa and Europe. Harmful Algae 7:692-701.

Harith M, Hassan R, 2011. Blue-green algae and nutrient concentrations in two Tor tambroides aquaculture ponds differing in construction. J. Trop. Biol. Conserv. 8:51-61.

Hawkins PR, Runnegar MTC, Jackson ARB, Falconer IR, 1985. Severe hepatotoxicity caused by the tropical cyanobacterium (Blue-GreenAlga) Cylindrospermopsis raciborskii (Woloszynska) Seenaya and Subba Raju isolated from a domestic water supply reservoir. Appl. Environ. Microbiol. 50:1292-1295.

Hawkins PR, Griffiths DJ, 1993. Artificial destratification of a small tropical reservoir: effects upon the phytoplankton. Hydrobiologia 254:169-181.

Hodgkiss IJ, 1974. Studies on Plover Cove Reservoir, Hong Kong: composition and distribution of the phytoplankton and its relationship to environmental factors. Freshwater Biol. 4:111-126.

Huszar VLM, Silva LHS, Marinho M, Domingos P, Sant' Anna CLS, 2000. Cyanoprokaryote assemblages in eight productive tropical Brazilian waters. Hydrobiologia 424:67-77.

Jacoby JM, Collier DC, Welch EB, Hardy FJ, Crayton M, 2000. Environmental factors associated with a toxic bloom of $\mathrm{Mi}$ crocystis aeruginosa. Can. J. Fish. Aquat. Sci. 57:231-240.

Jahan R, Khan S, Haque MM, Choi JK, 2010. Study of harmful algal blooms in a eutrophic pond, Bangladesh. Environ. Monit. Assess. 170:7-21.

Janse I, Kardinaal WEA, Agterveld MK, Meima M, Visser PM, Zwart G, 2005. Contrasting microcystin production and cyanobacterial population dynamics in two Planktothrixdominated freshwater lakes. Environ. Microbiol. 7:15141524.

Jayatissa LP, Silva EI, McElhiney J, Lawton LA, 2006. Occurrence of toxigenic cyanobacterial blooms in freshwaters of Sri Lanka. Syst. Appl. Microbiol. 29:156-164.

Jewel MAS, Affan MA, Khan FA, 2003. Fish mortality due to cyanobacterial bloom in an aquaculture pond in Bangladesh. Pak. J. Biol. Sci. 6:1046-1050.

Ji Z-G, 2008. Lakes and reservoirs, p. 509-565. In: Z-G Ji (ed.), Hydrodynamics and water quality: modeling rivers, lakes, and estuaries. J. Wiley \& Sons.

Joachimsen EM, Carmichael WW, An JS, Cardo DM, Coockson ST, Holmes CEM, Antunes BC, Melofilo DA, Lyra TM, Barreto VST, Azevedo SMFO, Jarvis WR, 1998. Liver failure and death after exposure to Microcystins at haemodylsis centre in Brazil. New Engl. J. Med. 338:873-878.

Jöhnk KD, Huisman JEF, Sharples J, Sommeijer BEN, Visser PM, Stroom JM, 2008. Summer heatwaves promote blooms of harmful cyanobacteria. Glob. Change Biol. 14:495-512.

Kemdirim EC, 2000. Diel rythym of plankton and physicochemical parameters in Kangimi reservoir, Kaduna State Nigeria. J. Aquat. Sci. 15:35-39.

Kemka N, Njiné T, Zébazé Togouet SH, Niyitegeka D, Monkiedje A, Foto Menbohan S, Nola M, Compère P, 2003. Quantitative importance of cyanobacteria populations in a hypertrophic shallow lake in the subequatorial African region (Yaounde Municipal Lake, Cameroon). Arch. Hydrobiol. 156:495-510.

Kitaka N, Harper DM, Mavuti KM, 2002. Phosphorus inputs to Lake Naivasha, Kenya, from its catchment and the trophic state of the lake. Hydrobiologia 488:73-80.

Kim, HR, Kim CK, Ahn TS, Yoo S, Lee DH, 2005. Effects of temperature and light on microcystin synthetase gene transcription in Microcystis aeruginosa. Key Eng. Mat. 277279:606-611.

Khoo HW, Yang SL, Goh CJ, 1977. A preliminary limnological study of Seletar Reservoir. J. Singapore Nat. Acad. Sci. 6:1-12.

Khuantrairong T, Traichaiyaporn S, 2008. Diversity and seasonal succession of the phytoplankton community in Doi Tao Lake, Chiang Mai Province, Northern Thailand. Natural History J. Chulalongkorn Univ. 8:143-156.

Komarek J, Azevedo SMFO, Domingos P, Komarkova J, Tichy 
M, 2001. Background of the Caruaru tragedy: a case taxonomic study of toxic cyanobacteria. Algological Studies 103:9-29.

Komarek J, Kling H, 1991. Variation in six planktonic cyanophyte genera in Lake Victoria (East Africa). Algological Studies 61:21-45.

Komarek J, Mares J, 2012. An update to modern taxonomy (2011) of freshwater planktic heterocytous cyanobacteria. Hydrobiologia 698:327-351.

Kotut K, Ballot A, Wiegand C, Krienitz L, 2010. Toxic cyanobacteria at Nakuru sewage oxidation ponds - A potential threat to wildlife. Limnologica 40:47-53.

Krishnan JR, 2008. Investigation on hydrobiology and water quality parameters of Periyar Lake, Thekkady, Kerala. Ph.D. Thesis, Mahatma Gandhi University, Kerala.

Kunz M, 2011. Effect of large dams in the Zambezi River basin: changes in sediment, carbon and nutrient fluxes. Ph.D. Thesis, Swiss Federal Institute of Technology, Zurich.

Lagos N, Onodera H, Zagatto PA, Andrinolo D, Azevedo SMFO, Oshima Y, 1999. The first evidence of paralytic shellfish toxins in the freshwater cyanobacterium Cylindrospermopsis raciborskii, isolated from Brazil. Toxicon 37:1359-1373.

Lewis WM, 1973. A limnological survey of Lake Mainit, Philippines. Int. Rev. Hydrobiol. 58:801-818.

Lewis WM, 1978. Dynamics and succession of the phytoplankton in a tropical lake: Lake Lanao, Philippines. J. Ecol. 66:849-880.

Lewis WM, 1986. Phytoplankton succession in Lake Valencia, Venezuela. Hydrobiologia 138:189-203.

Li R, Carmichael WW, Brittain S, Eaglesham GK, Shaw GR, Mahakhant A, Noparatnaraporn N, Yongmanitchai W, Kaya $\mathrm{K}$, Watanabe MM, 2001. Isolation and identification of the cyanotoxin cylindrospermopsin and deoxy-cylindrospermopsin from a Thailand strain of Cylindrospermopsis raciborskii (Cyanobacteria). Toxicon 39:973-980.

Lind OT, Davalos-Lind LO, 2002. Interaction of water quantity with water quality: the Lake Chapala example. Hydrobiologia 159:159-167.

Magadza CHD, 2006. Kariba reservoir: experience and lessons learned. Lake Reserv. Manage. 11:271-286.

Magadza CHD, 2008-2009. Re-eutrophication and pathenogenic contamination of Lake Chivero. In: M. Nakamura (ed.), Integrated lake basin management. International Lake Environment Committee.

Mahakhant A, Sano T, Ratanachot P, Tong-a-ram T, Srivastava VC, Watanabe MM, Kaya K, 1998. Detection of microcystins from cyanobacterial water blooms in Thailand fresh water. Phycol. Res. 46:25-29.

Mansoor H, Sorayya M, Aishah S, Mosleh MAA, 2011. Automatic Recognition System for some cyanobacteria using image processing Techniques and ANN approach. Proceedings Int. Conf. on Environmental \& Computer Science, Singapore, 19:73-78.

McGregor GB, Fabbro LD, 2000. Dominance of Cylindrospermopsis raciborskii (Nostocales, Cyanoprokaryota) in Queensland tropical and subtropical reservoirs: Implications for monitoring and management. Lake Reserv. Manage. 5:195-205.

Meesukko C, Gajaseni N, Peerapornpisal Y, Voinov A, 2007. Relationships between seasonal variation and phytoplankton dynamics in Kaeng Krachan Reservoir, Phetchaburi Province, Thailand. Natural History J. Chulalongkorn Univ. 7:131-143.

Merican F, Wan Asmadi WA, Wan Maznah WO, Mashhor M, 2006. A note on the freshwater algae of Gunung Stong, Kelantan, Malaysia. Trop. Life Sci. Res. 17:65-76.

Merino-Ibarra M, Monroy-Ríos E, Vilaclara G, Castillo FS, Gallegos ME, Ramírez-Zierold J, 2007. Physical and chemical limnology of a wind-swept tropical highland reservoir. Aquat. Ecol. 42:335-345.

Mhlanga L, 2011. Limnology of lakes and rivers (Zimbabwe). EOLSS Publishers, Oxford, UK. Available from: http://www. eolss.net

Mhlanga L, Day J, Chimbari M, Siziba N, Cronberg G, 2006a. Observations on limnological conditions associated with a fish kill of Oreochromis niloticus in Lake Chivero following collapse of an algal bloom. Afr. J. Ecol. 44:199-208.

Mhlanga L, Day J, Cronberg G, Chimbari M, Siziba N, Annadotter H, 2006b. Cyanobacteria and cyanotoxins in the source water from Lake Chivero, Harare, Zimbabwe, and the presence of cyanotoxins in drinking water. Afr J. Aquat. Sci. 31:165-173.

Mitrovic SM, Hardwick L, Dorani F, 2011. Use of flow management to mitigate cyanobacterial blooms in the Lower Darling River, Australia. J. Plankton Res. 33:229-241.

Mizuno T, Mori S, 1970. Preliminary hydrobiological survey of some Southeast Asian inland waters. Biol. J. Lin. Soc. 2: 77-177.

Molica R, Oliveira EJA, Carvalho PVVC, Costac ANSF, Cunhaa MCC, Melo GL, Azevedo SMFO, 2005. Occurrence of saxitoxins and an anatoxin-a(s)-like anticholinesterase in a Brazilian drinking water supply. Harmful Algae 4:743-753.

Molica R, Onodera H, Garcia C, Rivas M, Andrinolo D, Nascimento S, Meguro H, 2002. Toxins in the freshwater cyanobacterium Cylindrospermopsis raciborskii (Cyanophyceae) isolated from Tabocas reservoir in Caruaru, Brazil, including demonstration of a new saxitoxin analogue. Phycologia 41:606-611.

Moura AN, Dantas EW, Oliveira HS, Bittencourt-Oliveira MC, 2011. Vertical and temporal dynamics of cyanobacteria in the Carpina potable water reservoir in northeastern Brazil. Braz. J. Biol. 71:451-459.

Ndebele MR, Magadza CH, 2006. The occurrence of microcystin-LR in Lake Chivero, Zimbabwe. Lake Reserv. Manage. 11:57-62.

Nguyen LTT, Cronberg G, Annadotter H, Larsen J, 2007a. Planktic cyanobacteria from freshwater localities in ThuaThien-Hue province, Vietnam. II. Algal biomass and microcystin production. Nova Hedwigia 85:35-49.

Nguyen LTT, Cronberg G, Larsen J, Moestrup Ø, 2007b. Planktic cyanobacteria from freshwater localities in ThuathienHue province, Vietnam. I. Morphology and distribution. Nova Hedwigia 85:1-34.

Ochumba PBO, Kibaara DI, 1989. Observations on blue-green algal blooms in the open waters of Lake Victoria, Kenya. Afr. J. Ecol. 27:23-34.

Odokuma LO, Isirima JC, 2007. Distribution of cyanotoxins in aquatic environments in the Niger Delta. Afr J. Biotech. 6:2375-2385.

Oksanen J, Blanchet FG, Kindt R, Legendre P, Minchin PR, 
O’Hara RB, Simpson, P. Solymos GL, Henry M, Stevens H, Wagner H, 2013. vegan: Community Ecology Package. R package version 2.0-7. Available from: http://CRAN.R-project.org/package $=$ vegan

Okechukwu O, Ugwumba A, 2009. Cyanobacteria abundance and its relationship to water quality in the Mid-Cross River floodplain, Nigeria. Int. J. Trop. Biol. 57:33-43.

Okello W, Kurmayer R, 2011. Seasonal development of cyanobacteria and microcystin production in Ugandan freshwater lakes. Lake Reserv. Manage. 16:123-135.

Okello W, Ostermaier V, Portmann C, Gademann K, Kurmayer $\mathrm{R}, 2010$. Spatial isolation favours the divergence in microcystin net production by Microcystis in Ugandan freshwater lakes. Water Res. 44:2803-2814.

Oliver RL, Ganf GG, 2000. Freshwater Blooms, p. 149-194 In: B. A. Whitton and M. Potts (eds.), The ecology of cyanobacteria: their diversity in time and space. Kluwer Academic Publ.

Onyema IC, 2010. Phytoplankton diversity and succession in the Iyagbe lagoon, Lagos. Eur. J. Sci. Res. 43:61-74.

Orihel DM, Bird DF, Brylinsky M, Chen H, Donald DB, Huang DY, Giani A, Kinniburgh D, Kling H, Kotak BG, Leavitt PR, Nielsen CC, Reedy S, Rooney RC, Watson SB, Zurawell RW, Vinebrooke RD, 2012. High microcystin concentrations occur only at low nitrogen-to-phosphorus ratios in nutrient-rich Canadian lakes. Can. J. Fish. Aquat. Sci. 69:1-6.

Padisak J, 1997. Cylindrospermopsis raciborskii (Woloszynska) Seenayya et Subba Raju, an expanding, highly adaptive cyanobacterium: worldwide distribution and review of its ecology. Arch. Hydrobiol. 107:563-593.

Paerl HW, Fulton RS, Moisander PH, Dyble J, 2001. Harmful freshwater algal blooms, with an emphasis on cyanobacteria. TheSciWorldJo 1:76-113.

Pham MN, Tan HTW, Mitrovic S, Yeo HHT, 2011. A checklist of the algae of Singapore. Raffles Museum of Biodiversity Research, Singapore.

Piccin-Santos V, Bittencourt-Oliveira MC, 2012. Toxic cyanobacteria in four Brazilian water supply reservoirs. J. Environ. Prot. Ecol. 3:68-73.

Pongswat S, Thammathaworn S, Peerapornpisal Y, Thaneea N, Somsiri C, 2004. Diversity of phytoplankton in the Rama IX Lake, a man-made lake, Pathumthani Province, Thailand. ScienceAsia 30:261-267.

Poste AE, Hecky RE, Guildford SJ, 2013. Phosphorus enrichment and carbon depletion contribute to high Microcystis biomass and microcystin concentrations in Ugandan lakes. Limnol. Oceanogr. 58:1075-1088.

Prakash S, Lawton LA, Edwards C, 2009. Stability of toxigenic Microcystis blooms. Harmful Algae 8:377-384.

Prihantini NB, Widyawan A, Rianto R, Ariyani Y, Wardhana W, Hendrayanti D, 2008. Potential toxic cyanobacteria in three lakes of Jakarta-Bogor area, Indonesia. Mar. Res. Indonesia 33:95-100.

Prommana R, Peerapornpisal Y, Whangchai N, Morrison LF, Metcalf JS, Ruangyuttikarn W, Towproma A, Codd GA, 2006. Microcystins in cyanobacterial blooms from two freshwater prawn (Macrobrachium rosenbergii) ponds in Northern Thailand. ScienceAsia 32:365-370.

R Development Core Team, 2012. R: A language and environment for statistical computing. R Foundation for statistical computing, Vienna, Austria. Available from: http://www.Rproject.org

Ramberg L, 1987. Phytoplankton succession in the Sanyati basin, Lake Kariba. Hydrobiologia 153:193-202.

Ramirez P, Nandini S, Sarma SSS, Valderrama ER, Cuesta I, Hurtado MD, 2002. Seasonal variations of zooplankton abundance in the freshwater reservoir Valle de Bravo (Mexico). Hydrobiologia 467:99-108.

Rejmánková E, Komárek J, Dix M, Komárková J, Girón N, 2011. Cyanobacterial blooms in Lake Atitlan, Guatemala. Limnologica 41:296-302.

Retnaningdyah C, Soegianto A, Irawan B, 2010 Blooming stimulation of Microcystis in Sutami Reservoir using nutrients nitrate and phosphate in different ratio. J. Trop. Life Sci. 1:42-46.

Romero EM, 2002. [Determinación de toxinas biológicas en una fuente de abastecimiento de agua dulce].[Article in Spanish.] Proceedings XXVIII American Congr. of Sanitary and Environmental Engineering, Cancun, Mexico.

Rouf AA, Ambak MA, Shamsudin L, Phang SM, Ho SC, 2008. Temporal changes in the periphytic algal communities in a drowned tropical forest reservoir in Malaysia: Lake Kenyir. Lake Reserv. Manage. 13:271-287.

Rustadi, Kuwabara R, Kamiso HN, 2002. Water quality and planktological approach to monitor eutrophication by cageculture of red tilapia (Oreochromis sp.) at the Sermo Reservoir, Yogyakarta, Indonesia. Asian Fish. Sci. 15:135-144.

Sabart M, Pobel D, Briand E, Combourieu B, Salencon MJ, Humbert JF, Latour D, 2010. Spatiotemporal variations in microcystin concentrations and in the proportions of microcystin-producing cells in several Microcystis aeruginosa populations. Appl. Environ. Microbiol. 76:4750-4759.

Saker, ML and Griffiths DJ, 2001. Occurrence of blooms of the cyanobacterium Cylindrospermopsis raciborskii (Woloszyńska) Seenayya and Subba Raju in a north Queensland domestic water supply. Mar. Freshwater Res. 52:907-915.

Salonen K, Sarvala J, Järvinen M, Langenberg V, Nuottajävi M, Vuorio K, Chitamwebwa DBR, 1999. Phytoplankton in Lake Tanganyika - vertical and horizontal distribution of in vivo fluorescence. Hydrobiologia 407:89-103.

Sangolkar LN, Maske SS, Muthal PL, Kashyap SM, Chakrabarti $\mathrm{T}, 2009$. Isolation and characterization of microcystin producing Microcystis from a Central Indian water bloom. Harmful Algae 8:674-684.

Sant'Anna CL, Azevedo SMTD, Werner VR, Dogo CR, Fernanda RR, Carvalho LR, 2008. Review of toxic species of Cyanobacteria in Brazil. Algological Studies 126:251-265.

Sant'Anna CL, de Carvalho LR, Fiore MF, Silva-Stenico ME, Lorenzi AS, Rios FR, Konno K, Garcia C, Lagos N, 2011. Highly toxic Microcystis aeruginosa strain, isolated from São Paulo-Brazil, produce hepatotoxins and paralytic shellfish poison neurotoxins. Neurotoxin Res. 19:389-402.

Sant'Anna CL, Melcher SS, Carvalho MDC, Gemelgo MP, Azevedo MTDP, 2007. Planktic cyanobacteria from upper Tietê basin reservoirs, SP, Brazil. Rev. Brasil Bot. 30:1-17.

Sekadende BC, Lyimo TJ, Kurmayer R, 2005. Microcystin production by cyanobacteria in the Mwanza Gulf (Lake Victoria, Tanzania). Hydrobiologia 543:299-304.

Sim AJQ, 2009. Isolation of different cyanobacteria types from Singapore reservoirs. Nanyang Technological University. 
Sitoki L, Kurmayer R, Rott E, 2012. Spatial variation of phytoplankton composition, biovolume, and resulting microcystin concentrations in the Nyanza Gulf (Lake Victoria, Kenya). Hydrobiologia 691:109-122.

Sivonen K, 1999. Cyanobacterial toxins. Vesitalous 5:11-18.

Soares MCS, Marinho MM, Azevedo SMFO, Branco CWC, Huszar VLM, 2012. Eutrophication and retention time affecting spatial heterogeneity in a tropical reservoir. Limnologica 42:197-203.

Sotero-Santos RB, Silva CR, Verani NF, Nonaka KO, Rocha O, 2006. Toxicity of a cyanobacteria bloom in Barra Bonita Reservoir (Middle Tiete River, Sao Paulo, Brazil). Ecotox. Environ. Safe. 64:163-170.

Sprober P, Shafik HM, Presing M, Kovacs AW, Herodek S, 2003. Nitrogen uptake and fixation in the cyanobacterium Cylindrospermopsis raciborskii under different nitrogen conditions. Hydrobiologia 506-509:169-174.

Stewart I, Seawright AA, Shaw GR, 2008. Cyanobacterial poisoning in livestock, wild mammals and birds - an overview, p. 613-637 In: H.K. Hudnell (ed.), Cyanobacterial harmful algal blooms: state of the science and research needs. Springer.

Smith VH, 1983. Low nitrogen to phosphorus ratios favor dominance by blue-green algae in lake phytoplankton. Science 221:669-671.

Te SH, Gin KYH, 2011. The dynamics of cyanobacteria and microcystin production in a tropical reservoir of Singapore. Harmful Algae 10:319-329.

Tendaupenyu P, 2012. Nutrient limitation of phytoplankton in five impoundments on the Manyame River, Zimbabwe. Water SA 38:97-104.

Teixeira MGL, Costa MCN, Carvalho VLP, Pereira MS, Hage E, 1993. Gastroenteritis epidemic in the area of the Itaparica Dam, Bahia, Brazil. Bull. Pan American Health Organ. 27:244-53.

Tyagi MB, Singh DP, Kumar A, Jha PN, Sinha RP, 2006. Hepatotoxicity of Microcystis aeruginosa strains growing as blooms in certain eutrophic ponds. Exp. Clin. Sci. J. 5:66-78.

Van der Westhuizen AJ, Eloff JN, 1985. Effect of temperature and light on the toxicity and growth of the blue-green alga Microcystis aeruginosa (UV-006). Planta 163:55-59.

Vasconcelos V, Martins A, Vale M, Antunes A, Azevedo J,
Welker M, Lopez O, Montejano G, 2010. First report on the occurrence of microcystins in planktonic cyanobacteria from Central Mexico. Toxicon 56:425-431.

Vieira JMdS, Azevedo MTP, Azevedo SMFO, Honda RY, Corrêa $\mathrm{B}, 2003$. Microcystin production by Radiocystis fernandoi (Chroococcales, Cyanobacteria) isolated from a drinking water reservoir in the city of Belém, PA, Brazilian Amazonia region. Toxicon 42:709-713.

Vieira JMdS, Azevedo MTP, Azevedo SMFO, Honda RY, Corrêa $\mathrm{B}, 2005$. Toxic cyanobacteria and microcystin concentrations in a public water supply reservoir in the Brazilian Amazonia region. Toxicon 45:901-909.

Wang X, Parkpian P, Fujimoto N, Ruchirawat KM, DeLaune RD, Jugsujinda A, 2002. Environmental conditions associating microcystins production to Microcystis aeruginosa in a reservoir of Thailand. J. Environ. Sci. Heal. A. 37:1181-1207.

Welker M, Chorus I, Fastner J, 2004. Occurrence of cyanobacterial toxins (Microcystins) in surface waters of rural Bangladesh - pilot study. Federal Government Agency Berlin, Germany.

Werner VR, Laughinghouse IV HD, 2009. Bloom-forming and other planktonic Anabaena (Cyanobacteria) morphospecies with twisted trichomes from Rio Grande do Sul State, Brazil. Nova Hedwigia 89:17-47.

Wiegand, C, Pflugmacher S, 2005. Ecotoxicological effects of selected cyanobacterial secondary metabolites a short review. Toxicol. Appl. Pharm. 203:201-218.

White SH, Fabbro LD, Duivenvoorden LJ, 2003. Changes in cyanoprokaryote populations, Microcystis morphology, and microcystin concentrations in Lake Elphinstone (Central Queensland, Australia). Environ. Toxicol. 18:403-412.

Xu Q, Chen W, Gao G, 2008. Seasonal variations in microcystin concentrations in Lake Taihu, China. Environ. Monit. Assess. 145:75-79.

Yang SL, Chiam-Tai YC, 1991. Algae and algal blooms in Singapore reservoirs. Public Util. Board Res. Develop. J. 3:17-27.

Zurawell RW, Chen H, Burke JM, Prepas EE, 2005. Hepatotoxic cyanobacteria: A review of the biological importance of microcystins in freshwater environments. J. Toxicol. Env. Health 8:1-37. 